\title{
Creating Space for Belonging within the West Virginia Progressive Movement
}

Roger A. Jennette

West Virginia University, rarunner@mail.wvu.edu

Follow this and additional works at: https://researchrepository.wvu.edu/etd

Part of the Human Geography Commons

\section{Recommended Citation}

Jennette, Roger A., "Creating Space for Belonging within the West Virginia Progressive Movement" (2018). Graduate Theses, Dissertations, and Problem Reports. 3742.

https://researchrepository.wvu.edu/etd/3742

This Thesis is protected by copyright and/or related rights. It has been brought to you by the The Research Repository @ WVU with permission from the rights-holder(s). You are free to use this Thesis in any way that is permitted by the copyright and related rights legislation that applies to your use. For other uses you must obtain permission from the rights-holder(s) directly, unless additional rights are indicated by a Creative Commons license in the record and/ or on the work itself. This Thesis has been accepted for inclusion in WVU Graduate Theses, Dissertations, and Problem Reports collection by an authorized administrator of The Research Repository @ WVU. For more information, please contact researchrepository@mail.wvu.edu. 


\title{
Creating Space for Belonging within the West Virginia Progressive Movement
}

\author{
Roger Jennette \\ Thesis Submitted to \\ the Eberly College of Arts and Sciences \\ at West Virginia University
}

In partial fulfillment of the requirements for the degree of Master of Arts in Geography

Maria Perez PhD (Chair)

Daniel Renfrew PhD

Bradley Wilson PhD

Department of Geology and Geography

\author{
Morgantown, West Virginia \\ 2018
}

Keywords: Belonging, Progressivism, Activism, Community, West Virginia, Social Movements

Copyright: 2018 Roger Jennette 


\section{Abstract \\ Creating Space for Belonging within the West Virginia Progressive Movement Roger Jennette}

With the 2016 Presidential election come and gone, political activism within the United States has garnered more attention as political actors on the Progressive Left oppose the actions of the new administration. The West Virginia progressive movement is used as a case study of the national push towards progressive politics. Using participant diaries and a series of longitudinal interviews, this thesis explores the creation of spaces belonging within an activist organization to foster sustained involvement. Analysis points to the important of creating a sense of belonging and the desire to 'strive for better' in a state that is often perceived as left behind by the rest of the country. Battling an opioid epidemic, city-level fights for equal rights, attacks on the most impoverished, and constant push-back from the very people they are fighting for has taken its toll emotionally and morally on the activists. At the same time, the creation of constant contestation has created a space for belonging and friendship that otherwise may not have existed. This thesis also aims to contribute the broader conversation of what constitutes progressivism and how activist organizations use the term's ambiguity in their strategizing. 


\section{Table of Contents}

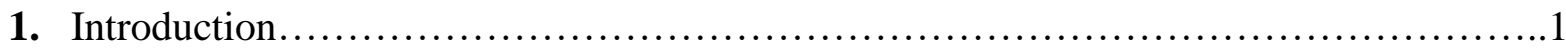

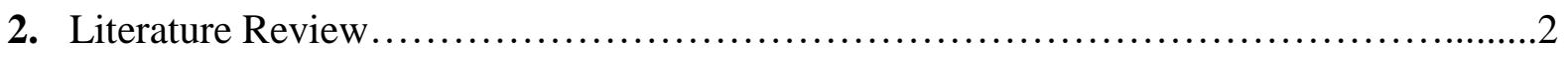

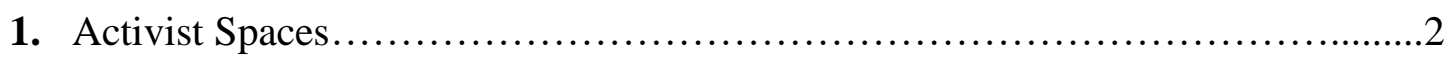

2. Personal Sustainability and Emotions ...................................4

3. Belonging and Home............................................... 6

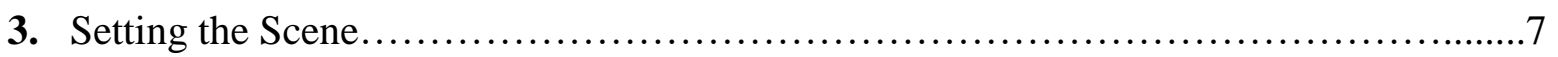

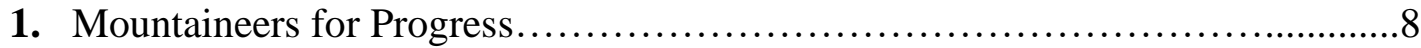

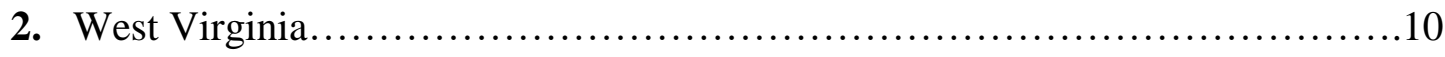

3. Defining Progressive Politics.......................................12

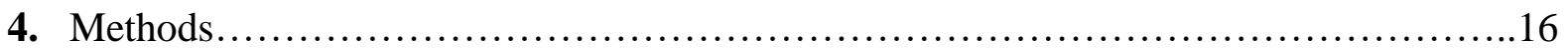

1. Research Questions............................................... 16

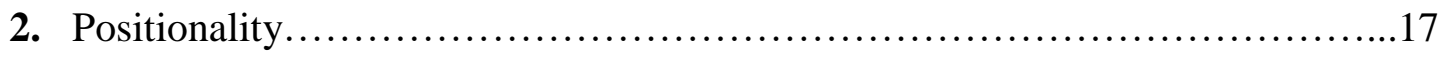

3. Participant Selection Criteria......................................... 18

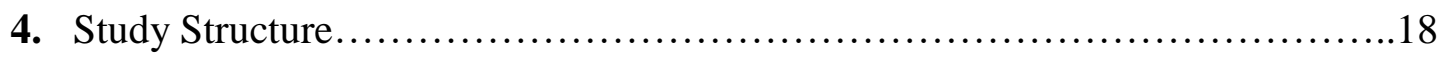

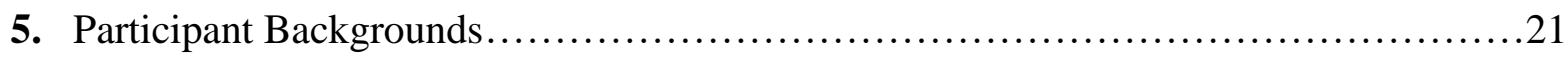

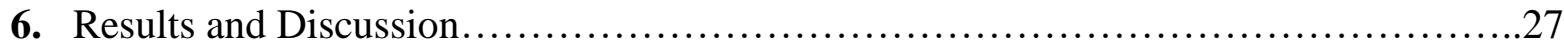

1. The Emotions of Activism............................................27

2. Belonging within the Movement.................................... 32

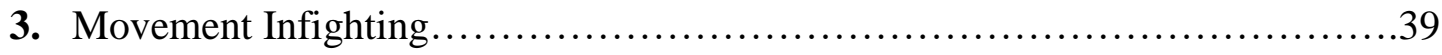

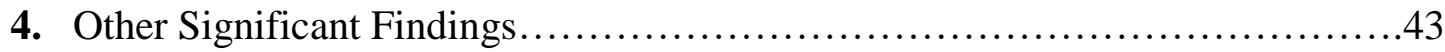

5. Reflections....................................................46

6. Summary of Findings............................................. 49

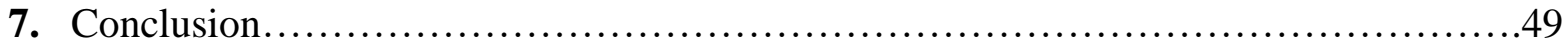

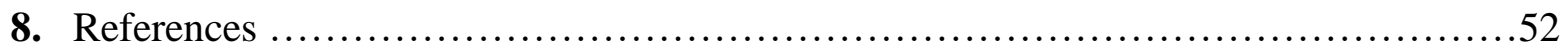

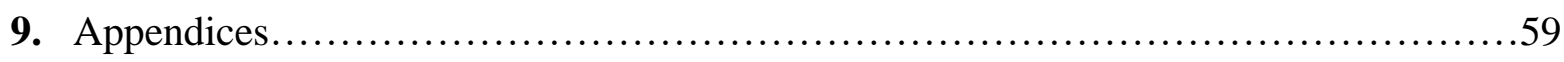

1. Appendix A: Interview Questions....................................59

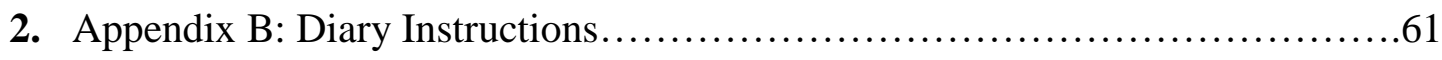

3. Appendix C: Photo-Diary Instructions..............................62 


\section{Introduction}

Since the recent 2016 presidential election, there has been a resurgence in political activism across the United States (Sydell, 2017). The results of the 2016 presidential election left nearly half of Americans, both Republicans and Democrats, anxious about the future of the United States (Bethune, 2017). It also left many others with a clear line of sight as to what they needed to do. This second group of people immediately began planning events in opposition to the new administration that would not take office for another three months. Among those voters who unequivocally supported candidates other than Donald Trump for the presidency, some saw his victory as a significant blow to the progress achieved by the United States over the past decade (Oppenheimer, 2016). There are also those who view Trump's election victory as a catalyst for progressive activism in the country. More specifically, West Virginia, wherein the recent presidential election 67.50 percent of voters supported Trump (New York Times, 2017), has seen a surge in progressive activism throughout the state through the actions of organizations such as Mountaineers for Progress (MFP), West Virginia Citizen Action Group, Wood County Indivisible, and the West Virginia Progressive Alliance. Many of these organizations were either founded or experienced a surge in membership in the time after the 2016 presidential election. In 2011 after the Occupy Movement, The New York Times defined the 'new progressive movement' as focused around three primary goals: (1) the revival of crucial public services, (2) reigning in Wall Street to prevent what caused the Depression in 2008, and (3) to reestablish the supremacy of voters over the dollar in government (Sachs, 2011). In a below section (C.1) I build on this definition of progressive politics by using explanations of how participants define progressivism from their first interviews.

To better understand the effect of the intimate and localized forces affecting activists of the contemporary progressive movement in West Virginia, my research focused on understanding the experiences of members of Mountaineers for Progress (MFP), a non-partisan Progressive organization located in Morgantown, West Virginia, and two participants of the first annual Grassroots Summit in Buckhannon, West Virginia, hosted by the West Virginia Citizen Action Group (WVCAG).

The original motivation behind this research was to discover what sustained West Virginia Progressive activists' political involvement regardless of continued losses in the face of legislation 
on local, state, and national scales. My initial questions focused on emotions: (1) how do progressive activists in West Virginia experience activism emotionally and (2) what are the effects of everyday life and emotions on the motivations and continued involvement of West Virginia progressive activists? As the research progressed, the research focus shifted to a a sense of belonging within a community of activists to understand this maintained political involvement.

The purpose of my work evolved from a primary focus on understanding the emotional and everyday experiences of activism of West Virginia Progressives to understanding these aspects of activism through the lens of belonging and community building within a political movement. Specifically, I focus on the importance of creating a sense of belonging on both the organizational and movement scales. I ask: How important is this sense of belonging on sustaining their political involvement on both local and statewide scales? Through this research, I highlight specific stories of progressive activism to ascertain what it is that sustains these activists to continue participating in the movement through the long-term. This research was conducted over a longitudinal eightmonth timeframe using semi-structured interviews, participant kept diaries, and participant observation to discern the emotional, embodied aspects of political activism over time. I have found that the creation of social spaces that facilitate the expression of emotions on a group scale and a sense of belonging within an activist organization is vital to the sustained action of political actors.

\section{Literature Review}

\subsection{Activist Spaces}

Activist spaces are transformed spaces where activists come together either in public such as a city park or train stations (Herbert, 2007; Nicholls, 2009; Amir and Kotif, 2015; Hopkins and Todd, 2015; Spiegel, 2015) or private, such as an activist's home or a private area within an activist camp (Brown and Pickerill, 2009; Burridge, 2010; Halvorsen, 2015). For this thesis, I use Massey's explanation of space as defined by three interwoven propositions: (1) space is the product of interrelations; (2) space is a sphere of possible multiplicities "in which distinct trajectories coexist; and (3) space is under constant construction and reconstruction, that "it is always in the process of being made. It is never finished; never closed” (Massey, 2005: 9). 
The public and the private spaces that fall under the broad idea of an activist space are connected as they are dependent upon each other, but they also serve separate purposes for the activists. The public aspect of activist spaces serves as means for the activists to gain visibility among those not involved in the social movement, to bring awareness to the issues that their movement is involved with (Askins, 2009). With this visibility, movements recruit more people, such as people joining in a march to protest government corruption (Mullis et al., 2016). Before these kinds of public actions can take place, they must be planned within a more private space (Askins, 2009). These private spaces can also extend into the virtual (Meek, 2012). Also, within this private activist space, the activists have a chance to reflect on and question the actions that were performed (Chatterton and Pickerill, 2010). Private space allows for the activists to create and maintain bonds with each other, motivating and expressing their emotions, along with living out the alternative futures they are trying to construct (Brown and Pickerill, 2009). Activist spaces, with this understanding, act as spaces where activists transform public and private spaces to plan actions and create bonds among themselves while attempting to live in a fashion like that which they are fighting for, bringing attention to their cause and to bring more people into their movement.

According to Nicholls (2009), if this activist space is to exist, it must do so within some form of place. Place is defined as the physical locations (the public parks, homes, meeting areas, etc.) that are transformed through the actions of activists from mundane places into place that reflect the activists that are occupying them, blurring the line between public and private, as can be seen in the Occupy Movement where those involved created private spaces in known public places (Halvorsen, 2015). These places rely heavily on the localized networks of the activists within the movements to construct and sustain their presence (Nicholls, 2009). I use the concepts of activist spaces and places to frame both where people act on their activist identities and to understand how they can effectively change the spaces around them, even temporarily, to fit into that identity. Activist spaces also feed into the necessary component of the important networks that are present within activism (Juris, 2008). Rarely is activism maintained in isolation. Instead, it is done amongst other activists who share a common ideology and goal.

The public and private aspects of activism are not solely reflected through activist spaces. There are parts of the activist identity that do not require the same level of performativity 
that activist spaces do. To varying degrees, people have lives outside of their activism no matter how entrenched they are in their movement. Activists do not simply exist within their activism, there are mundane aspects of life, their everyday lives, that exist outside the realm of their political involvement. This everyday life forms the foundation of who they are as people, not just as political actors. This research understands everyday life as consisting of people's jobs, what they do at home, what they decide to make for dinner, the trip to the store. The mundane of everyday life that generally falls outside of the activist's role as a political actor, I argue, is vital to the understanding of what motivations political activists.

\subsection{Personal Sustainability and Emotions}

Building on the public and private aspects of activism, this research focused on the personal and social aspects of activism, the emotions of those involved in activism. Building on work in emotional geographies (Bosco, 2007; Geoghegan, 2013; Botterill et al., 2016), I analyze the role of emotions in the personal sustainability that is required to maintain one's involvement in political activism. Emotions, from a psychological perspective, are defined as, "a coordination or composite of experiences, behavioral expressions and physiological/neurological components with varying duration" (Vikan, 2017, p. 3). Using this definition, this research understands emotions as a combination of the body's neurological processes and physical expressions alongside that learned behavioral responses to outside experiences. From an emotional geographies perspective, Bosco brings emotions into the sphere of activism through his concept of emotional labor which he defines as, “channeling, transforming, legitimating and managing one's own and others' emotions and expressions of emotions in order to cultivate and nurture the social networks that are the building blocks of social movements (2006, p. 343)." Here, emotions are not solely experienced and used by the individual expressing them, but instead as the 'building blocks' in which the movement is formed and nurtured. Emotions constitute the internal dimension of any social movement (Pulido, 2003). Emotional energy is equally important to physical energy in the maintaining happy and motivated people who continually contribute the movement (Laughton, 2006). 
The importance of emotions in activism can be seen at various stages from recruitment through 'moral shocks,' when the person is compelled to fight against something they deem morally irreprehensible (Jasper and Poulsen, 1995; Cass and Walker, 2009) to the possibility of becoming emotionally burnt out (Gorski and Chen, 2015). Within social movement studies, there is a need to understand the emotions of activists and protesters at a more nuanced level. This is a key contribution of my work which provides an in-depth analysis of the lives of activists both during and outside of their political actions.

Fear can be a profound motivating factor for activists. What begins as a 'moral shock,' as an intense emotional response when a person feels obligated to fight against something they deem morally irreprehensible (Jasper and Poulsen, 1995; Cass and Walker, 2009), can carry over into an intense fear that what 'shook' them in the first place may come to fruition. For Bauman (2006), "'fear' is the name we give to our uncertainty: to our ignorance of the threat and what is to be done" (p. 2).

On the opposite side of fear, or existing parallel to it is hope. Anderson defines hope as, a relation of suspension that discloses the future as being open whilst enabling a seemingly paradoxical capacity to dwell more intensely in points of divergence within encounters that diminish. Becoming hopeful is therefore different from becoming optimistic. It involves a more attuned ability to affect and be affected by a processual world because it is called forth from the disruptions that coax spacetimes of change into being within that world (2006, p. 747).

In other words, hope dwells on the possibility of change to happen without becoming necessarily optimistic. It thrives on the ability to coax that changes from specific space-times while also being open to being affected by those changes. Using this definition of hope allows for a better understanding of how activists remain hopeful even in times of immense fear and doubt and how they are constantly open to change and adaptable to the changes they are hopeful to enact. In understanding personal sustainably and the role emotions play in activism research can show that activism is a constant interaction between the individual and the group. Addressing the self can be equally as important as focusing on the group and movement. 


\section{$2.3 \quad$ Belonging}

Intimacy is the foundation of the creation of space to share the emotions of activism. According to Oswin and Olund,

Intimacy thus serves as a primary domain of the microphysics of power in modern societies precisely because it is a bridge to so-called larger relations of power. Kinship, procreation, cohabitation, family, sexual relations, love - indeed all forms of a close affective encounter - are as many matters of state as they are matters of the heart (2010).

Combining this argument of the intimate and geopolitical lens, Berelowitz (2005) uses intimate geopolitics to analyze the interconnections between the body, home, and border in the ways that artists represent the domestic spaces in the borderlands between the United States and Mexico. Smith (2013) uses intimate geopolitics to understand further the relations hidden from view but bordered in everyday space. By examining intimacy, a better understanding of the power relations that occur within the confines of the home, away from the public sphere, can be achieved. How these encounters and affects exude into the interactions, occurring within the public sphere can influence the personal sustainability of political actors.

Bringing this thesis together is the concept of belonging. Antonsich (2010) proposes thinking of belonging along two different analytical dimensions. The first is the placebelongingness which focuses on the personal, intimate, and the feeling at home in a place. The other analytical dimension is the politics of belonging that claims, constructs, justifies, or resists forms of socio-spatial inclusion or exclusion, recognizing different aspects of belonging, the personal and the social (Antonsich, 2010). One may feel as if they belong on one scale, and belonging to a group an another (Antonsich, 2010). Amin (2005) further suggests a 'new metaphor for belonging' that attaches belonging not to a specific group or territory but instead to a situation (i.e., activists who do not affiliate with any one organization but still feel as if they belong amongst other activists during a public protest). Belonging in this sense is a fluid action or response (Ilean, 2002; Kannabiran et al. 2006). Antonsich (2009) that also brings in the frame of 'communities of belonging' that can exist beyond 'communities of identity' that focus on likeness or sameness. By 
creating specific social spaces where individuals in the group feel as if they belong, activists can create a deeper sense of community within the movement and organization.

By aiming to create a sense of community within their movement, activist organizations transform spaces into specific activist spaces that reflect their desires and goals. In doing so, they also facilitate the expression of emotions that may have been the reasoning behind them joining the movement in the first place (Bosco, 2006). Farther complicating these emotions are the everyday lives of the activists that exist outside of their direct involvement and the effect that these lives have on their involvement (Halvorsen, 2015). The intimate connections that are formed among individuals within this community further promote the creation of a space (Smith 2013) that is not only based in political involvement but creates a sense of belonging among those who are invested in a movement's cause (Antonsich, 2010). It is this sense of belonging, alongside a desire to be around others who think and feel in similar ways to oneself, that lead into the facilitation of sustained involvement. In exchange for this community and effects maintaining each individual's motivations, the movement ideally can continue to operate with passionate members working to achieve its goals. My research uses these concepts to better understand the complex reasoning behind why activists in the West Virginia progressive movement stay involved and their motivations for doing so.

\section{Setting the Scene}

In this section and the subsequent subsections, I provide more information on both Mountaineers for Progress as an organization and West Virginia as the primary setting for this research. Within the West Virginia subsection, I will discuss briefly the other progressive organizations within the state that are relevant to this research and the Grassroots Summit held in the summer of 2017. I also attempt to define progressive politics based on definitions provided by participants.

\subsection{Mountaineers for Progress}

Mountaineers for Progress (MFP) is the organization that four of the six participants were recruited from. Most ethnographic notes are based on participant observation during activities and 
events of this organization. MFP was chosen for its location (it is based out of Morgantown, West Virginia near West Virginia University) and because I was already an active member within the organization and had established rapport with many of its members.

Before the 2016 elections, MFP served primarily as a social group for a small number of members, roughly 20-25 people. After the elections, MFP quickly grew in the number of members as local progressive searched for others who were frustrated about the election and fearful for the future. During this time, I joined the organization, witnessing its revitalization from a small group that hosted watch parties for televised debates into a large organization of over 200 members that sponsors public actions.

MFP is the most active progressive organization in the North/Central region of West Virginia. While it is based out of Morgantown and focuses much of its energy and resources in that area, it also extends its reach across the state. As quoted from their website, MFP is,

dedicated to the advocacy and support of progressive change in West Virginia. We have chosen to organize as an IRS 527 non-profit association, and we are registered as such with the Office of the Secretary of State for West Virginia. As a 527 association, our focus is on working on matters of local, regional and statewide significance where we may offer support of a non-monetary nature to local, regional and statewide political candidates not running for Federal office, but our primary focus is working to foster progressive change across the state (Mountaineers of Progress).

Officially, MFP on an organizational scale maintains a stance of nonpartisanship when it comes to party politics. This nonpartisanship is necessary for two reasons: (1) The organization argues that it is in its best interest to not side with one party or another to operate as a progressive organization in a conservative state and still attempt to attract a diverse set of members; and (2) It falls in line with their non-profit status as an IRS 527 non-profit association (they must be nonpartisan to retain this status). With this nonpartisanship in mind on an organizational level, many members either align with the Democratic Party, Mountain Party (or other Green Party affiliates), or are registered as independents. Many of MFP's members, including some on the MFP board, have recently been elected to serve in either a local public office or on the executive committee of 
the county Democratic Party. For the board members, this means they must soon resign their post on the board. That is not the case for regular members. Other members are currently running as candidates for state and national positions.

MFP is governed by an elected board that ranges from 5-9 members who serve two-year terms. All organizational proceedings are governed by a set of bylaws that were recently rewritten to reflect the organization that has grown over the past year. These new bylaws are up-to-date with how the organization is run. It was written by the new board and approved almost unanimously by all members present at the meeting. There are little expectations to be a member. A person can be as active or non-active as one chooses to be, but voting, attending meetings, and participating in public events and actions are encouraged. However, there are no repercussions for not doing so.

Membership in MFP consists primarily of middle-class and upper-middle-class residents of Morgantown, WV, and the surrounding area. Membership is obtained by paying a yearly membership fee of $\$ 10$. However, there are options for sponsorship or waving the fee if there is a financial burden. A majority of the membership is above the age of thirty with a small university student representation. This low student representation is interesting as MFP is based out of a university town. The students who are members are all graduate student, myself included. Funding primarily comes from members who donate to the organization and through various fundraisers hosted by MFP to fill its coffers.

MFP acts as a nexus for people who hold progressive ideals to come together, discuss and plan. The organization holds business meetings roughly every two weeks but this varies depending on the times of year and if other events are happening. MFP hosts a wide variety of events for its members and community including social events, public actions and protests, and candidate forums. MFP focuses on both national, state, and local issues depending on the time and the debates that are happening at the time. Recently MFP's board has been pushing to focus more on local issues where they believe they can have the most impact. 


\subsection{West Virginia}

West Virginia has a deep history of activism and social movements. Situating this year's teachers' walk-out with West Virginia's history of labor resistance, Kinney says,

Long before resistance was a hashtag, it was a bandanna. The red bandanna has been a sartorial thread in West Virginia history, dating back to at least 1877. That year railroad workers in Martinsburg, protesting a 10 percent pay cut, shut down the railroads and sparked the first nationwide strike in American history. Some of these workers began wearing red bandannas around their necks as a symbol of solidarity (2018).

Years after the ignition of a national railroad strike the late 1800's, West Virginia coal miners struggled for union recognition in events such as the Paint-Creek-Cabin Creek Mine War, the Battle for Blair Mountain, and the Matawan Massacre (Lewis, 2010). When U.S. District Judge Alston G. Dayton sided with coal companies in 1907, deciding that union organizers violated federal anti-trust laws, he gave the coal bosses a powerful tool to crush the unions, making the 1920's low point for labor organizing (Lewis, 2010). Later in the 1930's steel and chemical unions began to organize. Fast forward to 2018, the recent teacher walkout set off a wave of other teacher walkouts across the country (Lewis, 2010). The recent teacher walkout was not a part of the progressive movement that is the focus of this research. Instead, the walkout was organized considering the state's strong past of labor organizing that was supported by progressive organizations such as MFP. MFP served only to support the teachers during the strike, not in the planning or execution of the actions.

The contemporary progressive movement that is occurring in the state differs on various levels to labor movements of the past. West Virginia is seen as a 'Trump state' but also has a strong history as a labor and union stronghold as seen by the brief description above. West Virginia's long history of labor organizing presents an interesting background for this research. However, it is important to note that this history was not a focus of this research. While this history is vital to state identity and that of activists within West Virginia, it was not discussed at any length through the research process or in the data collected. As such, the brief discussion of social movements throughout the state provides background to further establish West Virginia as a viable 
location to perform social movement research. In the remainder of this section, I discuss other Progressive organization in the state, the grassroots summit, and why West Virginia was chosen as the location for this research.

The Grassroots Summit, which was hosted and organized by the WVCAG and a local progressives group in Buckhannon, West Virginia and held September 29-30, 2017, served as a venue for community leaders throughout the state to get together for workshops, to plan future events, and to network with other community leaders across the state. The Grassroots Summit served as both as a space to observe West Virginia's Progressive activists and to recruit multiple participants for this research.

Another major progressive-leaning organization in the state and a sponsor of the Grassroots Summit is the West Virginia Citizens Action Group (WVCAG), whose philosophy according to its website is,

That full-time citizen participation in the decision-making processes of our state is absolutely essential. Our staff and members work to increase the voice of the average citizen in public affairs through research, education, lobbying, organizing and coalition building - speaking out on behalf of the consumer, speaking out in defense of a cleaner environment, and speaking out in favor of a government that is honest, open, and accountable to the needs of all its citizens. We work to empower individuals by providing them with resources to be effective advocates on issues that affect/impact their lives (West Virginia Citizen Action Group).

While the WVCAG is not a focus of this study, Sarah's role in this research and WVCAG's role in progressive policy in the state make it a noteworthy organization and relevant to this study. The final organization that is relevant to this research is Ohio Valley Together (OVT) that is based out of Wheeling, West Virginia. The mission of OVT according to its Facebook page is to, "To unify and focus the efforts of like-minded community organizations in the Ohio Valley through education, collaboration, and public action" (Ohio Valley Together). Alex plays a major part in running this organization. Combined, these three organizations encompass a large part of the progressive politics within the state and touch 3 of the major regions of West Virginia: OVT in the 
northern panhandle, MFP in the North/Central Region, and WVCAG in the southern part of the state and the Charleston area.

West Virginia was chosen as the setting for this research due to its popular recognition as a "Trump" state, 67.5 percent of voters choose Trump for the presidency in 2016 (New York Times, 2017) and is the setting for a progressive movement continues to grow and expand. This setting allowed for a better a chance to understand a turbulent time in United States politics through the lens of the progressive movement that was growing in a state that in recent times leans politically towards conservatism. Also, the university in which this research was conducted through is a land-grant institution in West Virginia and has reasonable proximity to the state and the surrounding areas.

\subsection{Defining Progressive Politics}

In this section, I describe progressive politics (also progressivism) as defined by each of the participants of this research ${ }^{1}$ during their first interview. Sarah ${ }^{2}$ defines progressive,

In a very basic sense, as in opposition to regressive. So, if you're looking at it in an oppositional way, regression is that society should look to the past for answers and that changing social institutions or traditions is generally a bad idea. I feel like the opposite of that. I think society should always be re-examining itself and looking for new solutions and new ways of dealing with things. To me progressive means making progress towards achieving our values and goals $(1)^{3}$.

For Sarah, "Progressive" is defined in direct "opposition to regressive," believing that society needs to be in a constant state of reflexivity to find more innovative solutions to its problems. Katie defines progressivism in a similar manner to Sarah. To her, a progressivism looks toward the future for the betterment of everyone. In her words,

I will define progressive activism as looking toward what's going to benefit us in the future... The idea of progress to me is almost to reforming a lot or revamping

\footnotetext{
${ }^{1}$ Participant backgrounds are discussed in section E below.

2 The names of all participants have been changed to preserve their anonymity.

3 The numbers, ' 1 ' or ' 2 ,' refer to the interview in which that participant quote is pulled from. In the same respect, the letter ' $\mathrm{D}$ ' refers to that quote being pulled from the participant's diary.
} 
a lot these systems creating (e.g. Medicare. Medicaid, and Social Security) ... I read a statistic, I'm in (work in) education, a few years ago that said that 65 percent of the jobs that our current kindergarteners will have in the future haven't been invented yet. So, it's hard to decide what Progressive action is going to be cuz it's like 'what are we going to be looking at?' But progressive action to me is set around the environment. It's centered around people. It's centered around sustainability and everything that we're doing right now isn't sustainable. It's (current politics) whatever will last us 4 years until the next election and then the next one and then the next one it's so short-sighted so just looking in the longer term is progress to me (1) (clarification added by author).

For both Sarah and Katie, "progressivism" is about creating new responses to the problems that are facing society at that time based not on what may have worked in the past, but what can work in the future. Progressivism to move society forward is an idea that is shared by Alex as well. In the below quote she discusses how she views liberalism and progressivism as two different, but similar ideologies. She then draws from her experiences with West Virginia's Young Democrats to construct her definition of progressive politics.

I'm reading a book now and it talks about the difference between the word liberal and progressive. And how liberal has been used as a really aggressive talking point. It's a slur now. But essentially, it means liberty, freedom, self-expression that's unbound by the government but for me, progressive it means progress, moving forward. We young Democrats -- they have t-shirts and it says, 'Take West Virginia Back', and it has the word 'back' slashed and 'forward,' 'Take West Virginia Forward'. One quote makes so much sense, that 'progress does not mean you're Democrat or Republican.' You can be progressive and be a conservative, and I believe that. Might not be agreed to by some of my colleagues, but I definitely see that as a reality and being progressive means that you want others to be successful in the way that they understand success. If that's being married to someone they love, then so be it. If that's advocating for a population that they think is underrepresented, then so be it. That's being a political person or nonpolitical person. It's very wide. So, for me, the term progressive, although I identify as that 
politically, it's so broad. It's not a hateful word. progressive means being forwardthinking, and unbridled by hate. Like that's how I see it (Alex, 1).

Progressive politics for Alex can be summed up as forward-thinking, unbridled by hate, and advocating for others to be successful as they define success. In the below quote, Isabel, another participant, discusses progressivism as not an ideology that does not fear change.

I think not being afraid to change things. I don't think that we should change things for the sake of changing things. Like Betsy DeVos is an example of really terrible change. That's my inner teacher coming out I think, and I will never not be bitter about it as long as I live. But I think, yeah moving in a direction that helps people be more equal, to help things be more fair, to treat people more equitably. And to not hold it up because we've always done it this way. Or this is the way we do things and that's how it always is... I don't know. That's probably my slanted view of positive change. (1)

When asked how she defines 'positive change' immediately after this statement, Isabel continued to say,

That part is definitely not objective at all. I think a big part is just trying to make a more equitable society for everybody. And recognizing that there are a lot of groups who have not had to pay attention to how unequal things are. And kind of bringing that to the forefront and saying, 'Look at all these things that are disproportionately affecting women, or LGBT people, or people of color, or whatever the case may be.' And how do we go about addressing that in a way that's fair for everybody, that doesn't penalize white people? But that addresses people's concerns and makes things more fair. Makes things accessible to everybody on a more even playing field because we know it's not even (1).

Isabel, as a progressive, wants society to be equal for everybody and to do this, people first must realize that the entry of society is currently is not working towards the goal of equality. To do this, positive change must be worked towards. But she warns against change just for the sake of change.

Emma's definition of progressive activism comes with a more personal explanation that stems from her passion for helping people, particularly children. 
For me, it's (progressivism) about moving us... That is progressive activism for me. It is getting enough people to understand that that's fucking sick, and it's not who we are as human beings. It's not who we are as Americans. We need to move forward. We need to fight for what the true human values are, and we need to evolve. We need to help people evolve. If those fuckers are going to think that, 'Yeah, it's cool once it gets to my neighbor's, neighbor's, neighbor's kid starving,' then those fuckers need to be shut up. I'm all about people sharing their voice, but if it's hate and disgust like that, you shut up. (1) (clarification added by author).

Emma continues her explanation of progressivism by referring to a poster that was hanging in her office where this interview took place.

Racism, you shut up. Sexism, you shut up. Yeah, but raise your voice, everyone. I'm looking at a poster on my wall, for the record, that says, "Hear our voice, empowered, determined, and united," as I'm saying the words, "Shut up, " to a bunch of ... I think they were all conservative white males in my head, but you know the situation (1).

Nathan, during his interview, provided a concise definition of progressive politics that sums up the main points of the other five participants explanation of their views of progressive ideology.

I think progressives, in general, are for enacting social change, and also just keeping things on an equal playing field for economics and social issues, and using the government as a facilitator of that (1).

In establishing a definition of progressivism, I summarize and blend the views of my participants to create a workable definition of progressive politics for this research: Progressivism is a political ideology that forces society to be reflexive about itself to realize the social change that creates a better, more equitable future for everyone. By looking toward, the future instead of back at the past, progressivism advocates to reshape established social systems and to create a fairer accessible environment where people are free to peruse success regardless of what that success is. The backbone of progressive politics is the need to be innovative in creating sustainable 
solutions to present and future problems while rejecting hatred.

In the introduction to this thesis, I used the New York Times definition of the "new progressive movement" which focused around three primary goals: (1) the revival of crucial public services, (2) reigning in Wall Street to prevent caused the Depression in 2008, and (3) to reestablish the supremacy of voters over the dollar in government (Sachs, 2011). Alongside this definition, in an article for Dissent Magazine, Nancy Fraser identifies what she calls 'progressive neoliberalism.' She defines this as an alliance between new social movements such as the LGBTQ+ rights, feminist, and anti-racism movements and the corporate businesses of Wall Street and Silicon Valley (Fraser, 2017). She rejects this brand of progressivism. Instead, she reaches for a revitalization of the progressive politics that were seen during Bernie Sanders 2016 presidential campaign (Fraser, 2017. Both of these goals of a 'new progressive movement' and defining 'progressive neoliberalism,' the definition that I have given based on my participant's responses aligns with both the goals set forth and in continuing the work of Bernie Sanders campaign that Nancy Fraser calls for.

\section{Methods}

\subsection{Research Questions}

1. How do progressive activists in West Virginia experience activism emotionally?

2. What is the effect of everyday life and emotions on the motivations and continued involvement of West Virginia Progressive activists?

To answer my above research questions, I employed a mixed-methods qualitative approach which included the use of participant-kept diaries (Elliot, 1997; Latham 2003; Meth, 2003; Thomas, 2007), various types of interviews, and participant observation of organizational meetings. The dairies allowed me to delve deeper into the participants' motivations to continue their activist involvement than would otherwise be possible using interviews alone. Each method within this mixed-method approach will be discussed more in-depth in the following subsections below. 


\subsection{Positionality}

My experiences as both a graduate student and activist at West Virginia University shaped my research. Beginning in July 2016, during the presidential primary elections in the United States, I became an activist. As a graduate student, I then expanded that identity to an activistacademic (Askins, 2009), thus using my privileged position as a graduate student to facilitate my continued activism (McCorkel and Myers, 2003). As I have continued to develop my activist identity, I have created numerous connections throughout the state of West Virginia. These connections, along with my identity as an academic-activist and interest in the emotional aspects of political involvement came together in this research. Through the connections I share with fellow activists, I have been seen as an insider within the progressive movement of West Virginia (Hopkins and Todd, 2015).

As an active member of the activist community, not only did I continue to participate in the activism in the state, but this participation has allowed me to continue to create rapport with participants and facilitate their actions with the knowledge and resources I possess. By already being seen as an insider within the organization and the larger state-wide movement, I was able to forgo the necessary period of trust-building that accompanies fieldwork (Hopkins and Todd, 2015). While I argue that it has not affected the research in any other way than recruiting participants and building rapport, it is necessary to reflect upon my political views. In this thesis, I still aim to provide a critique of the progressive movement of West Virginia's ideals, institutions, and strategies alongside my analysis (DeLyser, 2001) Personally, I am a left-leaning progressive and as such my activism reflects these views. The activists who are participating in this research share a majority of these views since they were recruited from a progressive movement in West Virginia. Without these previous connections, it would have been improbable to complete this research within the timeframe provided to a master's student. Indeed, these established connections allowed me to complete the longitudinal framework of this study that would previously be difficult to accomplish. This longitudinal framework was adopted to better understand how motivations and identities of activism can change over time, allowing for a more than a single snapshot into the participants lives creating a more robust data. 


\subsection{Selection Criteria for Participation in Research:}

1. Be politically involved and identify as an activist.

2. Reside within the state of West Virginia.

3. Be actively involved in political activism, participating in a political action, event, or meeting on a regular basis during the research period.

4. Be willing and able to keep the reflection journal for the duration of the study.

For this study, six people matching the above criteria were originally recruited to participate. Four of the participants were recruited from MFP. The other two were recruited during the Grassroots Summit, one from Wheeling and the other from Charleston. However, after the first round of interviews, the participant from Charleston dropped out of the study. As such, she did not complete the journal or remaining two interviews. However, data gathered from her single interview is still included in the research. The other five participants who completed the study allowed for an in-depth analysis of the data gathered from each participant (Nelson, 2016). This number also allowed for the data collection and analysis to remain feasible within the timeframe available to complete this research.

\subsection{Study Structure}

This study followed a longitudinal framework, lasting approximately 20 - 23 weeks in total depending upon the participant. This slight variation stemmed from scheduling conflicts that arose throughout the study period. Consisting of three separate interviews, the study period for each participant began during the initial interview. All of the initial interviews began within a two-week period, hence the variation in the time frame stated above. At the initial interview, participants were given a journal to record their thoughts and experiences for the following 8-10 weeks until the second (diary) interview takes place and the journal returned. Following the second interview, most of the study period is complete. After the data was analyzed, I conducted a follow-up interview with each participant to member check the data and inquire about any new developments in their activist involvement. By using the format of a longitudinal study, I was able to gather a 
better sense of how the participants reflect upon the process of sustaining their involvement throughout the research period, comparing their experiences from the beginning of the study to the end and how they may have changed throughout by reflecting at the diary-interview. Each method is discussed more in-depth below.

The initial interview served as the introductory component of the study. The interview was semi-structured. The semi-structured interview model allowed for the interviewer (myself) to guide the participant through a set of topics, but the participant decided what aspects to emphasize within those topics (Longhurst, 1996). The primary focus of this interview was to provide a baseline for the data collected in both the diaries and the following two interviews; this included demographic data. Topics that were discussed included the participants' previous political involvement, their personal sustainability, their identity as an activist, and the connections they formed throughout their involvement (see Appendix B). At the end of this interview, the participant was given instructions for the reflection diary. At this point, any initial questions that the participant had about the study were answered. This interview marked the beginning of the diary period for the participant.

Details on the motivations, hopes, and desires of activists are vital to the understanding of why they continue to be engaged with political activism. The reflection diaries consist of solicited texts from the participants in a provided notebook (Latham 2003). Following Meth (2003), the diaries were prefaced with generalized instructions which were identical in all diaries. These instructions invited the participant to write whatever they wanted at the frequency and amount they desired. Alongside this broad petition for writing, the specific interests of the study were listed: personal sustainability, identity, and experiences while participating in political actions (see Appendix B). Starting from the date of the initial interview, the participants were asked to keep the reflection diary until the second (diary) interview.

Alongside offering unique insights into the lives of the participants, the reflection diaries allowed for an alternative route for the participants to express their emotions (Meth, 2003). According to Thomas (2007), a major advantage of solicited diaries is the participants' ability to express their thoughts in writing, thus avoiding potential upset or harm that could be caused during in-depth interviews regarding personal issues in the participants' lives. Solicited diaries also allow the participants to dictate their thoughts on their own schedule, recording their thoughts as they 
occur instead of having to wait for a formal interview (Meth, 2003). This method of solicited diaries emphasizes the voice of the participant, empowering them to share their insights and modify the power relations between the researcher and the researched (McDowell, 1992; Ansell 2001). In the case of the reflection diaries, it is important to acknowledge that unlike personal diaries, these are not private documents. Instead, the solicited diaries are specifically related to the study's purposes and "are written with a particular reader and their agenda in mind" (Elliot, 1997).

After the 8-10 weeks of keeping the diary, the second (diary) interview was conducted. The first part of the interview was done in the style of the diary-interview. For this interview, the diary became a kind of reportage for the participant's experiences. The diary-interview served to interrogate what has been written (Zimmerman and Wieder, 1977; Latham, 2003). Indeed, while simply completing the diary will provide more in-depth data, further integrating that data with the participant allowed them to expand upon and validate the written information (Cho and Trent, 2006).

The basic structure of the interview resembled a semi-structured interview. The primary difference is that I had access to the participant's diary during the interview and used it to guide the conversation as opposed to a set of predetermined questions and topics (Latham, 2003). Participants were asked to give me access to the diary before the interview took place. If the diary was completed in a digital format, the participant was asked to forward the document to me at least 24 hours before the interview. If it exists in the physical notebook provided, I asked that the participant allow me to read it before the interview briefly. I generally collected the diary form the participant at least 24-48 hours before the interview.

A follow-up interview took place roughly 10-13 weeks after the second (diary) interview. This interview was an opportunity for member checking the analyzed data from the participant diaries and interviews, further validating the data (Cho and Trent, 2006). The participants were presented the data for a final opportunity to correct and comment on the data. Also allowing me one last opportunity to obtain clarity on anything that may not have been entirely clear from either the diaries or previous interviews. 
Throughout the study, I conducted various accounts of participant observation that focused on three separate areas: MFP sponsored events and business meetings, informal gatherings of activists in Morgantown, West Virginia, and the two-day Grassroots Summit. These observations have added to the robust narrative and created a more in-depth analysis of the participants' involvement. During these observations, in-depth field notes were taken. When notes were not able to be recorded in the present, thoughts and observations were written down at the first available moment after the event or meeting had concluded.

All collected data were coded using five prominent themes that arose during the data collection process. These codes were: emotions, networking, personal and everyday life, West Virginia, and sustaining poplitcal action. All transcribed data were thoroughly analyzed by hand using one of the codes before moving onto the next code. In the case of the handwritten diaries, photocopies were made to leave the original document unedited. Once all data were coded by hand, the codes were transferred into NVivo software for further analysis and virtual storage.

In my original research proposal, I proposed the use of various methods that were not utilized in the study due to time constraints present to a Master's student that became more apparent during the research process. One of these methods was the photo diaries that would have accompanied the reflection diary. Participants were given instructions for the photo diaries but informed early in the study period that it would no longer be an active aspect of the research. However, if they wished to include photos with their reflection diaries, they were more than welcome to. While one participant did include scanned copies of newspaper clippings that reflected progressive actions in the area, they were not actively included in this research. The social media analysis also was not included in the study. While such an analysis would have added more depth to the research, it was ultimately dropped due to time constraints.

\section{Participant Backgrounds}

Below are brief descriptions of the backgrounds for each of the six participants who participated in this research. All names have been changed for purposes of anonymity.

\section{Alex}


I identify first and foremost as an advocate, and whatever that means. Less so than specific you know, advocate for mental illness, advocate for LGBT community, an advocate for people and when I decided my major, I really think I knew it at like 11. I really just felt akin to people and wanting to understand them better. Both their most horrible, most horrendous nature and why people wanted to even do good things for one another because we were so awful in so many ways. But I really do feel, Carl Jung talks about there's a goodness in people, there's an innate kind of goodness, and it might be burdened by the world, but essentially everybody has that good and wants to be loved and all those things. I look at it as a motto, as a philosophy. I identify as someone who just wants to make it, to relieve the struggle. I'm not a martyr, I'm not Mother Teresa over here, I definitely have needs And I'm selfish in a lotta ways, but I identify as an advocate (Alex, 1).

Alex is a lower-middle-class white transgender woman student living in Wheeling, West Virginia. She is 23 years old and currently a psychology student focusing on clinical psychology and sex and gender studies at a local private university in the area. Before she moved to Wheeling five years ago from an Amish community in central Ohio, she attended a small community college in the area where she grew up. While at the community college, Alex had her first foray into politics when she petitioned to get the student council president removed from office. Alex felt the president was not doing all she could to advocate for the students at the school. Advocacy is important to Alex, as it is reflected in all her politics and her career as the Associate Director of a local mental illness non-profit.

Alex once organized her clients to call their representatives every day to voice their opposition to healthcare reforms. They later received a letter in the mail from West Virginia Senator Joe Manchin thanking them for contacting him and sharing their opinions. Alex is also a member of the local Democratic Women's Club, the founder of a local organization, Ohio Valley Together, that brings together other progressive organizations, and a member of another local group of activists. If there is an event happening or a progressive group in the Ohio Valley area, she is likely to be involved in some capacity. 


\section{Nathan}

My wife's great. You know it's a little bit tricky. I think we talked about before, her schedule, she works late at night. So, a lot of things happen. You have to be there at like six. But my kids are 9 and 7 but they're very mature. So, you know they're out doing stuff whatever, I'll make them dinner, everything's ready. They're doing their thing. They come home they did and just wait for her to come home. So, it hasn't been bad. I know other people, you know they have to like a bargain and work out things like I get this night get this night or whatever. We don't really have too much of that so it hasn't affected my life that way. I think my wife realizes that she doesn't have time like she wants to be doing what I'm doing, but she doesn't have the time for it. So, she kind of views like I'm going to work. So, if you need to spend 200 dollars to make something happen, then that's her way of being able to be part of it without actually doing it so. I was going somewhere the other day and my kids were like were you going do you have to go where ever and I was like whatever my wife was like he has to go try to make it so you guys can have a future whatever. So, I think she realizes that's what we're doing. It hasn't been a problem (Nathan, 2).

Nathan is a 39-year-old upper-middle-class white male. He is originally from Pennsylvania but moved to West Virginia with his wife when she came here for her residency during medical school. She now works as a doctor while he is a stay-at-home father caring for their children. Being a stay-at-home father allows Nathan to invest more time and energy into his activism and community engagement. He does this both for himself and for his wife, who due to long work hours, cannot be as involved as she would like. He also brings his children to many of the events he plans as events director for MFP. For him, his children act as his primary motivator to be involved since he wants to leave a better community and country for them. He also has a master's degree in library and information science and worked as worked first as an elementary school teacher and then as a school librarian before choosing to stay at home raising his children. 


\section{Emma}

I always just had, in my personality, that I would feel obligated to or feel bad for folks who didn't have it as good as me, or folks who were just being pressed upon in some way. You go back even to grade school, and teachers always paired me up with the behavioral problem in the class because I just cared about people, and kids, and stuff. Even though sometimes I found that very annoying in elementary school, that I was always, "Emma, you don't get to be with your friends today. You get to work with Bobby, who's having issues again," I also found a sense of pride in that, I think. That's carried through my whole life (Emma, 1).

Emma is a 32-year-old middle-class white female from California who moved to West Virginia after receiving her $\mathrm{Ph} . \mathrm{D}$. in human development and family studies to teach and research as a tenure-track faculty member. Her work focuses on children's health in the state. In the above quote, she describes her personality as someone who wants to help people. Even at a young age, she was driven by this desire to help that has carried on to her adult life and into her current activism within MFP. She is a member of MFP's board. She also was a founding member of another progressive organization in Morgantown that was later absorbed in MFP. She has a daughter and husband. In college, she began to be more politically involved by going to protests. After President Obama was elected, she went into a state of complacency that she now feels obligated to make up for. She was hit hard by the election of President Trump after being so emotionally dedicated to Bernie Sanders presidential campaign.

\section{Katie}

I've been politically involved for a really long time, I was part of the young Democrats then and that big election was John Kerry. So, I phone banked at the time and went door-to-door and talked with people, held signs, did rallies, that kind of stuff. We lost badly. I can still remember sitting in the Democratic headquarters on election night watching those numbers rolling and being like 'no...' Then I moved up here to Morgantown and got involved with the Occupy Movement that happened a few years ago. I was their very brief treasurer where there was nothing to be done. I mean for the most part up until this year everything, I've done have 
been a solo thing because there hasn't been a network of people or a way to connect with people. So, I went to marches and to D.C. I would drive down for those, which I would take part in and just take part in anything I could find that was here at the time (Katie, 1)

Katie is a 29-year-old white female from Central West Virginia who graduated in 2010 with her B.A. in psychology. She currently works in the county school's system in northern West Virginia as the extended day director. She has lived in Morgantown, West Virginia, for the past 10 years having stayed in town after attending university there. She identifies herself as bisexual. She was single at the beginning of the research period, but during the study, she began a relationship with another activist from West Virginia who is not a direct participant in this research. She sees herself as a militant and progressive activist. She is involved in politics both for herself and for the children she works with as a part of the public school system. At the end of this research, she was also heavily involved in the senate campaign of a candidate for the House of Representatives seat in northern West Virginia. As a board member of MFP, she is a leader within the organization and is involved in many of the events and actions hosted by MFP.

\section{Isabel}

So, I'm already kind of involved in that. I was always really interested in politics. I worked for the campaigns before I could vote. I've made phone calls. I don't want to tell you which campaigns because I was young and I didn't know what I was doing. And then when I lived overseas briefly, started working in the TESOL field. And most of my students were Arabic speakers, Muslim students. And so, I ended up involved with particularly when the Muslim ban kind of nonsense started. That was a big deal for me. I did a little bit of prison literacy (Isabel, 1).

Isabel a 27-year-old white female from Pennsylvania who moved to West Virginia as a teenager. She attended university in West Virginia getting her bachelor's degree in music education and a master's degree in English as a second language. She spent the few years after getting her master's degree teaching English to university exchange students before starting her career as the outreach coordinator for a national non-profit organization. She got originally involved in politics and activism as a student of the arts through having to fight for funding constantly. She is married 
to a primary school teacher and was heavily involved in the recent teachers' strike in West Virginia on both professional and personal levels. Originally, she had wanted to leave the state and move on but stayed for her husband. In time, her desire to stay in the state grew while her husband began to want to leave.

\section{Sarah}

One thing I like to say about myself is that I'm a professional troublemaker and the reason I say that is, one of my personal heroes is Congressman John Lewis from Georgia... He likes to say, 'you know I think people should be getting in more trouble, getting in good trouble, necessary trouble.' That's what I think of. I think activists are people that sometimes inconvenience others. You know it's not always pretty or clean. But activists are people who are trying to draw attention to injustices and to solutions (Sarah, 1).

The above quote comes from Sarah, one of the two transgender women who participated in this research. Here, she is describing what she considers 'activism.' I use this quote to provide a better sense of how Sarah describes herself, as a professional troublemaker. Sarah is a 32-yearold transgender woman currently living in Charleston, West Virginia. She is originally from the Charleston area, where she went to school for part of her childhood before moving to Hurricane, West Virginia, where she finished high school. Afterward, she attended Marshall University, changing her focus of study multiple times. After three and a half years at Marshall, she left with a technical certification in computer networking and no bachelor's degree. She reflects on her migration out of Charleston by describing her journey West up the Kanawha Valley and then returning to Charleston later in life. She has a desire to stay in the state to help change it. As a native West Virginian, she feels a connection with the state, and a responsibility to help push it into a future that aligns with her progressive ideals.

Sarah works for the West Virginia Citizen's Action Group (WVCAG) in what she calls 'formal activism.' As the outreach coordinator for the organization, she oversees organizing and connecting with groups and individuals that share common goals with WVCAG. Aside from working in 'formal activism' and holds the political identity of a Progressive, she identifies herself as a transgender, queer, lesbian. A couple of years ago, her transgender identity was challenged by 
the state DMV which resulted in Sarah joining a lawsuit against the state to overturn a law that required state workers to 'correct' those they thought were impersonating another gender. The lawsuit was eventually successful in the years to come. She is also the participant that dropped out of the study after the first interview.

\section{Results and Discussion}

Although their responses differ in many aspects, many of the participants discussed similar themes during both their interviews and diaries. In this section, I present the major findings of this study. Alongside this review of the findings, I discuss what they mean for this research and the progressive movement in West Virginia. I identified three major themes:

1. The Emotions of Activism

2. Belonging within the Movement

3. Infighting within the Movement

Each of these is addressed below in the sections that follow. I then highlight other significant findings from this research.

\subsection{The Emotions of Activism}

The world is a very sad, violent place right now... for a pacifist... someone who doesn't believe in guns or war... I'm really struggling on a personal level with how to combat the seemingly pervasive despair/hopelessness that certainly plagues us in West Virginia but also fighting/revealing the evil that exists (Emma, 1).

Emotions are part of all aspects of our lives. In the above quote, Emma expresses her feelings about the world. As a pacifist, she sees the world as a place that she struggles to come to terms with, one in which she feels a need to engage with and change for the better. These distinct feeling of despair, hopelessness, and yearning for a better world are expressed universally among all five of the research participants. In each interview and in the journals kept between them, the 
participants repeatedly reflected on these and many other emotions that they experienced throughout not only the study period but throughout their involvement over the past year. Some included excerpts from past journals written outside of the study or reflecting upon events that occurred before the research began.

When this research was originally proposed, its focus was on understanding the underlying emotions that aided in, or limited, the continued involvement of activists in West Virginia. After completing this research, I have found that emotions alone do not solely facilitate continued activist involvement. Emotions are present in all actions but are not always the driving force behind these actions (Bosco, 2006). Using these emotions, actors can use them as a motivating factor. In other words, emotions play a major role in activism, but not to the extent of manipulating the person, or persons, feeling them perform in a specific way, taking away them agency.

Throughout the interviews and journal entries emotions are explicitly brought up and discussed, there are countless times, especially in the interviews, that a switch in the participant's tone of voice or facial expression would change to express an emotion that could not be captured through voice recording or witnessed in transcriptions. These physically expressed emotions are equally as important as the emotions that were specifically discussed. For example, during her second interview, Emma began to cry when discussing the healthcare reforms going through Congress and how she believed that children would die if it was passed. By listening to the audio recordings, it was not evident that she was crying until she explicitly mentioned it. However, this is something I took note of during the interview. These gestured emotions are expressed and read through their unique cultural lens in which they exist. It is important to keep in mind that what these emotions may appear to be expressing to those viewing their expression may be different than the actual emotion it is expressing (Vikan, 2017). While myself as the researcher may have implied a certain emotion being expressed that was not captured by the audio recording, what the person was intending to express may have varied from what was assumed or be entirely different. This difference between the expression of emotion and its understanding by others follows through to how emotions play a larger role within political activism in West Virginia and the interactions between actors (Bosco, 2006).

Within West Virginia's progressive movement, hope plays a vital role among many motivating factors of involvement that can vary between individuals. As the motivations of each 
individual are unique, a hope for a better future has been a common theme for involvement among my participants. Using Anderson's (2006) definition of hope, “a relation of suspension that discloses the future as being open whilst enabling a seemingly paradoxical capacity to dwell more intensely in points of divergence within encounters that diminish (p.2)." In the following quote from Nathan's diary shows that while the present is a mix of emotions, he is still hopeful towards the future,

"What I can say at this point is that the year has been one full of hard work, disappointment, fear, hope, failure, and some success all wrapped into one. Everything about this year has been chaotic since President Trump took office. One thing that has remained a source of hope and pride in my work with other dedicated grassroots organizers who sacrifice their time and energy in trying to keep things from going off the deep end!" (Nathan, D).

For Nathan, hope stems from the organizers he works with. Even though the past year has been full of negative emotions, his continued action and hope that a better future is possible stem the actions of others. Discussing hope in the language of emotions, alongside fear, despair, happiness, etc., allows for it to become a part of the emotional conversations instead of an outside influencer upon the emotions. To fully realize the impact of hope upon the activists in the research; hope must be discussed alongside other emotions that both stem from and interact with it. In the above quote from Nathan's diary, hope acts as a balance for the plethora of negative emotions that have defined the last year for him. If it were not for his hope and pride for both the future and the people shaping it, he might have had no reason to be involved.

I now want to turn attention the discussion to specific emotions that came about throughout this research. While many emotions were expressed by participants throughout this research, below I bring attention to two specific emotional responses: sadness/despair and happiness. These played important roles in mapping out the emotional turbulence of the participants' involvement as an activist over the course of this research. While their trends of emotions acquiring, the order in which each emotion is discussed below does not reflect those trends. 


\section{Sadness and Despair}

I was really saddened when Bernie lost, and then just horrified when Trump did it. I literally went into a hole. The first three days and this is really sad and talks about how stupid and naïve and ideal I still am, but the first three days, anytime I saw a black person, I just cried. It is the stupidest thing, but I just cried. It was horrifying (Emma, 1).

Those within the progressive movement argue that the contemporary progressive movement came into existence when Bernie Sanders announced his campaign for the presidency in 2015(Leland, 2016). His campaign brought countless young people and other previously uninvolved, and uninvested, people into the political sphere (Leland, 2016). While his campaign may be where the movement got its start through the hoping for a better future, it was after November 8th, 2016 that the movement gained new momentum, one based on sadness, despair, and fear. As Emma mentions in the quote above, when Trump was elected, she went into a depressive state. This is a common sentiment across the participants of this research. It is also a sentiment that others in MFP share.

In the below quote, Isabel speaks of her frustrations with the Representative in the House for the Morgantown area in Congress. This is a sentiment echoed amongst member of MFP that I have seen throughout my research. They are frustrated with his, and others representing the people of West Virginia, inaction or blatant ignoring of their constituents. As Isabel says below in her journal,

I know that more people are paying attention, and there will certainly be a push to oust many members of Congress, it doesn't help the current helpless feeling I have in situations like these. As useless as it is to say, it's not right, it's not fair, and it's not what people like these are supposed to be doing. It's infuriating and discouraging to keep encountering roadblocks when this person is responsible for representing so many people. I hope that representatives who choose not to represent will see the consequences of their callous and irresponsible actions when they're up for reelection (Isabel, D). 
In their attempt to combat policies they see as wrong, these activists have also created social spaces of comfort, whether they be at someone's home (private), at a bar (public), space where they can express their emotions and work towards overcoming their despair and sadness caused by current political setbacks. The creation of these spaces of comfort stems from the extension of the emotional labor that goes into activism (Bosco, 2006). By socializing their emotions, the actors involved have created a space where they can collectively express and come to terms with these more adverse emotions as a group. Even if this was not the purpose, or even acknowledged by those involved, having this space to be comforted among others feeling similar emotions is just as important as the actions they are planning. For local activists, having someone represent them in government, who in their minds does not represent their interests or even acknowledge them can be infuriating and defeating. However, it also has acted to bring activists together who may not have worked together on other issues under the umbrella of a candidate challenging the incumbent. In the last few weeks of this research and in the months since progressive activists across the North/Central region of West Virginia have turned their despair and frustration of the actions of their representatives into successful candidate campaigns. Instead of wallowing in their despair, they have decided to work to enact change.

Seeing how this movement has grown and that helps keep me going cause if there was no one else beside me, Ifeel like I would have given up in despair a long time ago. I would not have known what to do with everything that is happening but there's always somebody to turn to now, so it helps... Just seeing people care that's really it, like I know that sounds so simple. (Katie, 1).

Like Emma, Katie was wrought by Trump's election. For her, as she says in the above quote if it wasn't for the other activists that she is fighting and organizing with, she would not have known what to do with everything that is happening. Since his inauguration in January 2016, many members of the progressive movement in West Virginia have been defensive against constant policy attacks from Washington D.C. and Charleston, West Virginia. For Katie, seeing others involved, being passionate about trying to enact positive change is what keeps her going in the movement. This use of others as a motivation to continue being involved is a topic I touch on in the following section (R.2 Belonging within the Movement). 


\section{Happiness}

I'm just happy to have found so many like-minded people, and it's incredibly refreshing to see them kick back and have fun since we so often gather to work on stressful and emotionally draining problems (Isabel, D).

Even at a time, and within an organization, that has become more active based on a sense of despair for the future, those involved have managed to find the time and space to facilitate their own and others' happiness. As Isabel discusses above in her diary, it's a refreshing feeling to be around others who think like her and to see them enjoying themselves. This is what brings her happiness. Within this specific space and time, Isabel felt at ease; she could push aside her feelings of dread and anger, emotions that are likely shared among the other activists present in this space, and simply enjoy the moment. Especially these spaces have primarily taken place at events hosted by MFP or by its members. Creating spaces like this that focus on the mental wellbeing of those involved within the organization has become a goal of MFP as it sponsors social and other events that step away from the political and more towards groups bonding (this is discussed more in depth in the following section 6.2 Belonging within the Movement).

\subsection{Belonging within the Movement}

A significant finding from this research was the importance of 'belonging.' As discussed above, the creation of a sense of belonging is seen in the literature as a vital aspect of the success of a social movement (Amin, 2005; Antonsich, 2010). This is no different within the West Virginia progressive movement. For Katie, answering the question as to how she continues to be involved in the movement, she answered,

Honestly, it's the people and the group, I feel like a lot of the people that I've met over this year like their passion was my big thing. I was doing this alone for so long, and that was fine, but it just felt like I was screaming into nothing like I couldn't get any of my friends to care enough to show up to anything. I still have that problem... so for a while, it was just super lonely, it was like I wanted to do things and change things, but it was just felt impossible. But this doesn't feel 
impossible now that everyone's here... We have like 200 members in Mountaineers for Progress but I feel like a core 40 or 50 people show up repeatedly for things and that might not be a lot especially with everything that we're trying to accomplish, but still I feel like we do a pretty good job passing things back and forth to each other and picking up when one of us is kind of lagging and needs a couple days (1).

In the months directly following the 2016 election, Katie felt as if she was alone in her anxiety and hopelessness for the future. She was unaware, and this research has found that many progressive-leaning people were during this time in northern West Virginia that she was not the only one who felt this way. While she was involved in politics before joining MFP, her involvement was as limited to solitary actions as her activist network was essentially non-existent. The friendships in her life were not providing the support she needed, nor were they sharing in her desire to enact change in the way she was. This is a common sentiment held among the participants and other progressives in West Virginia whom I met during my fieldwork. This movement has done more than attempt to challenge the politics of the state, it has also allowed people who felt alone to come together with others who otherwise may have never interacted to form bonds of friendship. Isabel verifies this during her first interview, "I do think it's really cool to see how many people I've met. All the people that I didn't know. This is on the more selfish side of it. But there are so many people that I never... I wouldn't have known if not for all of these things" (1). She may consider the building of these personal friendships as being selfish, but it is these friendships that create the foundation of the movement. "Finding people to coax you back from madness" (2), Katie states in her second interview is one of the most important parts of building these bonds within the movement.

\section{MFP's Organizational Shift in Planning Events}

The established bonds among MFP members are continually reinforced through business meetings, public actions, and social events. Over the past year, MFP has held regular formal business meetings varying from every week to every other week depending on the political environment of the time. Originally, when the organization was still smaller in the months following Trump's' inauguration, these meetings resembled more of a social atmosphere with discussions focused on organizational business seen as a secondary priority. As MFP has grown 
to encompass over 200 active members and maintains contact with roughly 2000 'friends' as of early 2018, the social aspect of these meetings has been replaced with those of the organization's needs. MFP has not thrown aside this social aspect of its origins as it grew. Instead, official social events such as picnics, get-togethers, and other events to get the membership and community together in a non-formal setting, began to take form. Nathan, the events director of MFP who organizes these events, explains the importance of social events to the organization:

I think as events director that's definitely something I'm going to be trying to do the best I can to try to find things like that that are free and available to people because it is important and you know the evidence shows that groups that do things together socially get more done collectively because you're not just going to meetings and talking about things, you're actually forming bonds. You know, you have potluck dinners so you're sharing food. Your kids are playing or whatever. That's why churches do it. That's why the Tea Party, like the Republicans, have been really good at that kind of thing through the churches. They have, you know, so but I think that's an important thing to give people a reason to do things to show up to besides just work (Nathan, 2, edited by the author for clarification).

Nathan sees bringing people together outside of the work of the movement as vital to its success. In the forming of these bonds, a sense of belonging is created for those in the movement. Flesher (2016) shows the importance of creating a sense of collective solidarity in the creation and sustainability of transnational movements. Building on Flesher, I argue that this collective identity is an essential step in the creation of the sense of belonging that is vital to the maintenance of local and transnational movements alike. For Isabel, designating a time and place to devoted to fun and relaxing is important:

I think building in fun activities with people you already really like being around and do all this work with, it's nice to just kind of build them in so that it's just it's there. It's an option, and you can relax and have fun and rest a little bit I guess (Isabel, 2).

Later, during the same interview, she revisits this topic, but in a more formal setting of a fundraiser. 
Yeah, I think people are slowly trying to figure out ways to ... Well, like when we did a fundraiser for Planned Parenthood, it was like a paint and sip... I mean I painted George O'Keeffe vaginas, so it was a fundraiser, so we were still kind of doing some amount of work, but it was like a relaxing like, "Let's get together and drink mimosas and paint vaginas, " which is not a thing I thought I would be doing, but I think people are coming up with really cool creative ways, kind of bring everything together and find ways to relax and have fun and maybe even be productive at the same time towards the goals that they're working on (Isabel, 2).

Organizing potluck dinners and painting George O'Keeffe vaginas are not the only activities in which bonds are created and reaffirmed. While these events organized for the movement help foster a sense of belonging to the organization, they are not the only way to do this. Informal events for members of the movement, but not officially through the organization are equally as important, if not more so, for belonging. In the early days of MFP, these informal meetings took place after the business meetings at a local bar over drinks, where a majority of the work and brainstorming for the organization happened not in the business meetings themselves. These after 'business happy hours' were extremely productive in both the sense of work getting done and friendships being formed. Later, such gatherings would happen at member's private homes, as Isabel says in her diary:

Every once in a while, in the nonstop barrage of ugly statements and policies, something simply fun and enjoyable happens. Tonight, was one of those nights, as lots of activists got together to relax and celebrate Halloween. I know this isn't really an entry about anything to do with activism, I'm just happy to have found so many like-minded people, and it's incredibly refreshing to see them kick back and have fun since we so often gather to work on stressful and emotionally draining problems (Isabel, D).

Having been at this Halloween event, I saw firsthand the importance of events like this one that focuses on relaxing and being oneself among a select group of friends from within the movement. This event was hosted by Emma on Halloween weekend in 2017 at her home in Morgantown. A majority of those in attendance were MFP members and their spouses. A few people in attendance were not a part of MFP but knew someone who was. People dressed up in 
costumes and most were drinking alcohol. Here, professional performances that are normally present during official events were put on hold. While conversations occasionally turned towards politics and more official business, it was in a light-hearted spirit with no decisions needing to be made at that time. On the creation of these friendships, Emma shares the struggle of making friends as a mother,

I've met bunches of new friends. It's hard to do that in your adult life, especially when you have kids because everyone's like, 'I have to be home with my kid,' including myself. That's been really great. Tons of new social connections, and friends, and interesting ideas, and new people to connect to (1).

Because of her involvement, she has been able to connect with many people that otherwise she may not have had the opportunity of connecting with. As we saw in the previous section and will continue to see below, it is these created connections that sustain her involvement and those of the other participants.

Before the 2016 election, most of these people were strangers. Now, including myself, most of us are not only comrades within a movement but have formed deep friendships. Isabel records a similar sentiment in her diary,

The biggest silver lining that has come out of all of this ugliness is that people that I have been able to meet and work with, some of whom have become truly great friends. It's really wonderful - and necessary. I think - to have friends who understand these difficulties and struggles (D).

While the creation of new friendships is in and of itself valuable to participants, the support networks that have come from them are what I have found to be an important aspect when understanding why people stay in the movement over the long term.

\section{MFP's Transformation of Space}

MFP regularly utilizes the space of a local bar and show venue for its events, particularly social events. This space itself is imbued with artifacts and hints of social norms that those who typically occupy it reinforce. When MFP's events take place, this space is transformed, albeit temporarily, into an activist space to reflect instead the ideals of those activists that now occupy it 
en masse. While the physical attributes of the space remain, they are not as prominent in the minds of those present as they may be for those whom space normally entertains. Instead, the people, conversations, and shared habitus create an atmosphere that is conducive to that of the progressive activist. This space is temporarily transformed into what the literature refers to as an activist space (Askins, 2009; Brown and Pickerill, 2009). Instead of seeing this activist space as unique to the specific time and place, these created activist spaces can instead be transferable, flowing from one

space to the next, carried along by the group, by each individual body, that inhabits the space, not bound to space itself. Carried along with this space, are the already existent bonds and sense of belonging that are established and re-enforced in such spaces. In this light, the bar facilitates already present emotions and ideals. It plays host to the activists who carry them along from one venue to another. Similarly, within these carried activist spaces, spaces of belonging as fluid, transferable, and mobile as the people who feel they belong to this group. The presence of their bodies manifests the space and sense of belonging in relation to the emotions and desires of those present. In this sense, space does not alone create belonging, the people do and the space as a part of a dynamic relationship do, space and specific place facilitate the creation of a space that reflects those interacting with it. Those assembled act in a dialectic with space's atmosphere, shaping it if only temporarily to reflect their emotions changing the spaces meaning (Wilkinson, 2017).

\section{Burnout}

Since the 2016 elections, the West Virginia progressive movement has been responding to various legislative 'attacks' and have taken many of what they consider "losses." In any case, with the amount of 'losses' the movement has endured, many of the activists have begun to burn out or have already become burnt out. However, throughout the last year and a half, very few people within the movement, in the case of MFP, have left for good. Instead, people have taken short sabbaticals from being involved, as Katie discusses in her interviews,

Ifeel like anytime I start to really feel burnt out, somebody else is really picking up steam and I might just sit out a day or two and cry or scream or sleep or not do anything. But then it's inevitable, like Shane. Shane wore out a couple months ago and had that big 'I'm not going to be a part anything political anymore I'm stepping out' we were all like 'no,' and there was so much support for him, saying that 
'you've done so many good things keep it up.' Now he's back. So, it's just leaning on those other people (Katie, 1)

I feel like all of us went through waves of just crashing out, like Shane you know, at one point was like 'I've got to step out for a while.' He's done that, I think, multiple times and a lot of us have. I feel like I've taken little sabbaticals. We have kind of in turns, and it's like we can't all do it at once. But if we have good people who are going to pick up while we're gone, that's such a relief. You don't feel like 'oh I'm letting the movement down,' it's like 'no there's plenty of good people within it and they will shoulder this till I can come back.' It's a good feeling (Katie, 2).

Over the past year, many activists within MFP including many of this research's participants have taken breaks because of burnout. Others have taken time off to stave off burn out. These breaks were discovered through discussion directly with participants and/or with other MFP members during events and meetings. In both cases, this was made possible through the support networks that have grown during and after the 2016 election. These support networks, alongside developing a language for self-care, have allowed for activists to sustain their motivation without fearing that by taking a break they are failing the movement as there is someone else to take up the mantle of their activism while they are away. However, this ability to step away is one of privilege that may not be available to other activists in other movements or even others within MFP. I discuss MFP as a privileged movement more in-depth in the 'Other Significant Findings (R.4)' section below.

Through this research, I have come to realize the importance of both creating a sense of belonging to the movement and promoting self-care. The creation of networks within a movement is vital to its success. It cannot be fueled by fear of loss or the hope for a better future alone; people must feel that they belong (Amin, 2005; Antonsich, 2009). When activists allow others to take up their work while they take care of themselves, the sustainability of both the individual and the movement is extended. On a personal level, as an activist myself, I have realized that without others and knowing when to take time for oneself, any social movement will fizzle out, as no one 
can keep the pace that is necessary without others to support them and tell them when it is time to take step back and recharge.

\subsection{Movement Infighting}

We just we have no mercy on each other. We're so passionate, and we just rip each other to shreds over little things. It's important to challenge each other, I think that there's no one within our group who doesn't have a viewpoint that could use some touch-up or some education around it, all of us can grow and do better and know more but this whole infighting thing that I see all the time, it scares the crap out of me because this is how they got us last year. Are we really going to do this again? We have to at least pretend that we're playing better than this. If there's one thing that the Republican party is, it's organized. If they have a message, they all get behind that message even if it's terrible... We have a really hard time doing that (Kaite, 1).

In the previous section, I discussed how some members of the progressive movement in West Virginia, particularly MFP, work to create a space in which those involved feel as if they belong. In this section, I will focus on what Katie discusses in the above quote, infighting within the movement. Many of these quotes will focus primarily on the MFP. In the above quote, Katie talks about how the people within MFP are so passionate that when they disagree, they have no mercy on each other. This creates a polarizing divide within the movement in two primary ways. First, it creates distinct camps within the movement. For example, within MFP there are two major camps with differing ideas. There are the more moderate progressives that make up much of the organization. These are the people who are working to change the system of government to reflect their ideals. The minority group within MFP are the more radical 'burn it all down' group of people within the organization. This group generally has a lot of emotions, primarily anger, that its members express in specific ways that are meant to anger elected officials. This is not to say that those in the first camp are not radical or vice versa. The primary distinction that I am making between these two groups is how they both go about enacting change and how they express their emotions and frustrations, both through the rest of the organization and to those outside if it. Katie 
best describes the distinction between the two groups in the below quote from her first interview by differentiating them by whom they supported after the Democratic party's primary in 2016,

I see a ton of infighting among our own people, and that's kind of hard to deal with.

We are all very passionate we all have a lot of ideas, but we have just as many people who almost refused to budge on what it is that they believe and when it comes to things like all people are people I understand not budging on that. But there are policies that to be realistic you have this Bernie versus Hillary faction of people those who voted for Bernie but then got behind Hillary when it was time to do that, and then those who refuse to do that because of principle or whatever because they believed in that whole progressive platform I think we all do but what is realistic (Katie, 1).

In the remainder of this section, I will be focusing on how infighting has been prominent within MFP. Also, I address how a small group of people can cause frustrations and harm to the movement.

All social movements will experience some sort of hostility from someone outside of the group. Within MFP and other progressive organizations in West Virginia, activists generally see this type of extreme hostility, while annoying and sometimes damaging, as a sign of the success of the movement. The extreme hostility acted as a source of verification that what they are doing is just, that anything worth changing will result in pushback. With this idea of outside hostility in mind, I turn to Emma's comment on in-group hostility,

I've felt hostility primarily from in-group. I think it's the greatest challenge facing us on the progressive side... I fight against it, but it's really tricky, because of our ideals. We have perfection and idealism, and we want everyone to be the perfect person, and no one is. When we fight each other for not being perfect, we're not fighting the other side for being really shitty. There's definitely been a lot of hostility. Mostly it's from in-group, which is really horrifying (Emma, 1).

Here Emma is acknowledging that infighting is a major problem within the movement. Like the quote from Katie at the beginning of this section, she notes that much of the infighting stems from how people think, whether they be passionate, perfectionists, and/or idealists these preexisting 
ideas on how the movement, and those within it, are the primary cause of the intergroup conflict. During my field observations, I noticed that during business meetings for MFP, ideological disagreements were mostly handled well and the following discussions were civil. However, more of the conflict arose when it came to strategies for public actions such as events and protests. For example, during the Grassroots Summit, we found out that President Trump was going to be visiting Morgantown, West Virginia (where MFP is based) the week after the summit. While it was agreed upon unanimously that an action was to be held, the fundamental problem arose when trying to decide what type of action it would be. One group wanted to hold a 'take a knee' protest outside the venue to reflect the current movement among professional athletes during that time, incorporating West Virginia University's college athletes. The other group wanted to hold a more family-friendly event and fundraiser for Puerto Rico, which had just been hit by Hurricane Sandy weeks before, which would act as a counter-event to the one President Trump was a part of. Nathan spoke about this event during his first interview,

There were people who wanted to do a certain type of protest, and there were people who thought we should do a fundraiser. So, we had all these different things. But the idea was, we're still all under the same umbrella. We all want to send the same message: that we don't like him, we don't like the policies that they're doing, and there are people here who want to express that. And it caused a lot of tension. It wasn't just like, "Oh, hey, we have different views. Let's talk about it." And it turned into, like, it could have... It showed cracks... It showed cracks. And I think we did a decent job of mending those cracks, or at least talking about it and being aware of them. But that to me is both the biggest challenge and the biggest, like, epiphany: that there are just people who have these thoughts and we have just to make sure that we all stay under the same umbrella. Because we are. At the end of the day, we are. We just feel differently (Nathan,1).

This event is of great significance as it was the first major case of infighting to occur within MFP since its revitalization. As Nathan states, 'it showed cracks' in the organization. After these cracks were shown between the two groups in the planning for Trump's arrival in Morgantown, the event ended up being canceled, and Trump never came. However, the two events that were planned in response to his arrival still happened. The first, a 'bend the knee' rally and march happened at a 
much smaller scale than would have happened. This event was not sponsored by MFP. However, the march led to the other event, a fundraiser for Puerto Rico at a local establishment that was hosted by MFP. This compromise was vital to the 'mending of those cracks' that Nathan spoke about above. While both events were held in separate spaces and by different groups, they ultimately shared participants and the same goal, to oppose Trump's policy agenda and rhetoric. In sharing this same goal, we come back to what Nathan said in his first interview, "so I think it's just we have to remind ourselves that we all are on the same team for now" (Nathan, 1).

One thing that takes an enormous toll on our energy is interpersonal conflicts among various people who have different strategies and ideas on how to make the best use of our energy. It's almost as taxing as fighting the GOP and Trump administration! (Nathan, D).

In his diary, Nathan brings up an important point regarding morale within the movement. He writes about how much of an emotional toll is extracted from the internal conflicts that occur within the movement, more specifically Nathan is talking here about MFP. Over the past year, there were a few people who exacerbated the creation of spaces of exclusion for other members. One such case was when a male member repeatedly made sexist comments to female members. He would also show up to business meetings intoxicated and attempt to take control of the meeting. After being confronted by a group of female members, he resigned his membership and left MFP. In this case, one member continually attacked the sense and space of belonging that the other members had worked to create over the past year.

Another instance of major infighting within MFP occurred when a well-known community member and organization leader repeatedly harassed community and MFP members through social media. This went on for almost a year. When she was finally confronted with threatening parents during the West Virginia teachers strike for possibly crossing a picket line, she resigned her membership to the organization. Both examples are aimed at showing how fragile a sense of belonging is within a social movement organization. This sense of belonging must constantly be reinforced and affirmed. When members are made to feel uncomfortable with the group, it is important that the source of that ingroup discomfort, which is different from the discomfort that can generally be felt throughout the movement from its surrounding, be addressed. This is especially true if the discomfort stems from other activists. But these moments of conflict also act 
to reinforce the collective identity, commitment, and sense of belonging of those who remain after the conflicts resolved. I end this discussion on movement infighting with a quote from Nathan's diary,

I would follow some of them to the gates of hell. Others, not so much! Interpersonal differences once (again) rear their ugly head and create challenges where there should be victories and conflict where there should be cohesion. I don't understand why some people draw a line in the sand over trivial things. The literal future of our country depends on us and other organizers, and we're fighting over the wording in a document! (Nathan, D, emphasis added by author).

\subsection{Other Significant Findings}

In this section, I briefly highlight significant findings that I was either not able to fit into another section, did not have enough data to analyze more in-depth in this thesis, or simply wanted to expand more upon with my thoughts separate from the other sections. I also include possible questions for further research regarding some of these findings.

\section{LGBTQ+ Leaders in the Movement}

An interesting side note of this research is that five of the six people who participated in this research were members of the LGBTQ+ community. Emma, Katie, and Isabel all identify as bisexual women. All three women are either married to or in a monogamous relationship with men. Alex and Sarah identify as transgender females. Nathan was the only participant in this study to identify as straight. Participants were not recruited intentionally based on their sexual orientation. Before the research began, even though I had known Emma, Katie, and Isabel beforehand, I did not know they identified as bisexual until the first interview. In the case of Alex and Sarah, they were both recruited at the Grassroots Summit, but not recruited because they are transgender. In fact, they were two of the people I had spoken with the most at the Summit, and in turn, I inquired if they would like to participate. Also interesting is that both Transgender participants are the only participants who do not live in or near Morgantown, West Virginia. Alex is from Wheeling in the northern panhandle of the state, while Sarah is from Charleston, West Virginia. 
It would be interesting for further research to explore the prevalence of LGBTQ+ individuals who are leaders within their local activist groups, not only in West Virginia but across the country. Specifically, within more progressive-leaning groups, since all five participants are leaders or founding members of progressive organizations in West Virginia. Were these participants already a part of the movement? Were they able to embrace their LGBTQ+ identity beforehand within the movement? Have they always been leaders, possible with no one knowing of their sexual orientation? Or has the contemporary movement brought them out into activism?

It is also likely that these individuals were already involved in some capacity as being a part of the LGBTQ+ is by default a political action. With recent events, such as the 2015 Supreme Court marriage equality ruling, many people in this community had already been actively involved in politics for some time in their fight for equality (Morris, APA). The progressive movement may just be their most recent political endeavor. For example, both Alex and Sarah expressed that their very existence is political. Sarah in fact, as mentioned in her description, was a part of a lawsuit in West Virginia to challenge driver's license photo law that required DMV officials to confront anyway too appeared to be impersonating another gender.

\section{MFP as a Privileged Movement}

Being one of only a few students in MFP (most students who are involved in the organization are graduate students), it appears that a clear majority of those involved are from middle and upper-middle-income households. Some of the younger members, generally in their late twenties, could be more from lower-middle income households. But in general, most people who are involved in MFP are financially stable. This brings up the question, is MFP a privileged movement? Many of those involved are fighting for their rights in some capacity, for example, the Non-discrimination ordinance battle in Morgantown or the fight over the abortion amendment across the state. It would be interesting to look at MFP through the lens of socioeconomic status and levels of involvement. Are people with more stable incomes more involved than those who don't have that privilege? Are those who are not threatened by current policy changes more involved than those who are not threatened but have more time and resources to be involved? Where do MFP's resources come from? 
It is important to note that MFP is comprised of a majority of white people with a small majority of African Americans involved as well. Those within the organization have realized that it is primarily white and there has been a push to recruit more people of color, with some success. The board of MFP is comprised of all white members. However, a leader within the organization is an African-American woman, although she does not serve on the board.

\section{Saving West Virginia}

When I asked Katie why she decided to stay in West Virginia, this was her answer:

I think West Virginia is kind of like the canary in the coal mine for the rest of the country and like the canary is dead. We are dying, so it's seeping out into other places, and it's like, I don't know, something needs to be done... I just believe if you're going to change things you have to be willing to stick around and make some serious personal sacrifices. I know that I would be I genuinely happier person if I did not live here. I know that, but I also don't believe that my life is about me, I believe it's about doing what we can do for everyone else while we're here and if West Virginia is going to come back out of this and not just turn blue again but be alive again, there either has to be some of us who are willing to lay everything on the line and just make that human sacrifice in order to get things going again here (Katie, 1).

Like many others in MFP, she is dedicated to staying and helping the people of this state in any way she can, even if this comes at the personal cost of her happiness. She has an attachment to this state, for her it is home. Many of the progressive activists within the state see West Virginia in this way. By seeing the state as their home, a place they live in, they are more apt to want to not only defend it from what they perceive as attacks but also to improve it (Berelowitz, 2005; Brickell, 2012). This spatial reasoning of home extends past the physical wall and property lines of their home to expand to boundaries of the city (i.e., Morgantown) and the state (West Virginia). recognizing the state as home provides a source of motivation to continue to be politically involved. 


\subsection{Reflections}

Through the past few years as a political and community activist, from being a volunteer for Bernie Sanders' campaign for the presidency in 2016 to leading marches in Morgantown, West Virginia I have questioned, like Nancy Frasier, what exactly are progressive politics (Frase, 2017). Above, I attempted to answer this questions through both the analysis of my participant's answers to that very question and delving into the thoughts of other thinkers within the progressive movement. After I wrote the above section on progressive politics (3.3), my question remains largely unanswered. Instead, it has only become more complicated. This thesis focused on analyzing how creating space for belonging within a local social movement organization fosters activists to remain involved due to the networks of support that is created. In coming to this conclusion, I have answered another aching question that has haunted me since the days of Bernie Sanders' campaign, the very question and struggle that originally fueled this research, how do the other activists not get burnt out from the constant fighting and loss? The answer I found is simple; it's the other people involved, those friendships made through struggle.

However, with this new-found wisdom of stemming burnout in MFP, an organization I have worked with for almost two years at the time of writing this thesis, my questions and concerns about the contemporary progressive movement have only grown. In the remainder of this section, I will reflect on several questions around progressive politics that stem from this research and my work as a community organizer in West Virginia within the movement. (1) Is progressivism to flexible (2) Is the ambiguity of progressivism sustainable? (3) How could and does MFP use the ambiguity of progressivism in their strategizing?

Above I narrowed down a definition of progressivism based on my participant's thoughts. Nancy Frasier complicated that definition with her arguments against progressive neoliberalism claiming that contemporary progressive politics is too intertwined with neoliberal capitalist forces to enact the change my participants are fighting for (Frase, 2017). However, regardless of her critiques of the neoliberal type of progressivism, this does not make it any less part of the progressive movement than Bernie Sanders' campaign. What Nancy Frasier, in my reading of her article, is arguing for is a more radical type of progressivism free from capitalist forces. While MFP may not be the most radical of progressive groups, within conservative West Virginia, they are viewed as radical in some of their views. This is where the flexibility of progressivism becomes 
vital to MFP's continued survival. Without a solid definition of what makes a progressive, activists in MFP have been able to shape the meaning of the term to reflect what its members what it to be. With a flexible, adaptable definition in their hands, they can take many debates that cross the aisle between republicans and democrats, and more importantly those who do not vote solely along party lines, to decide as collectedly as a local community how to respond as progressive activists. Their agreed stance on an issue does not necessarily have to agree with other progressive organizations across the country, or the state or region, to still be considered progressive within this specific community. It also allows them to adapt to the needs of their local community and not that of the distant national.

Whether this localized progressivism is sustainable in the long run is to be seen. While it allows activists to reflect the needs of their community, it also risks ostracizing others like the infighting that is discussed in section 6.3 of the results. Some of the conflicts discussed stemmed by disagreements in strategizing that ultimately came down to difficult differences in ideas and how to direct passion into action. For MFP, their sustainability may rely on their use of progressivism's ambiguity in whether they continue to engage on a large scale with national debates, or instead choose to focus their energy on local issues. If they focus on local issues, adapting progressivism to the local will only aid in their continued need for members and resources as they attempt to garner more substantial support based amongst locals while still holding true their core ideals. However, if they stray too far into national debates, they risk over asserting their localized progressivism against other groups who may define progressive politics in differing ways that challenge MFP's in the face of broader debates that extend past West Virginia's needs.

Though progressivism as an ambiguously defined term may be beneficial to MFP, is it a sustainable model in an age where the local can quickly become national in the age of the internet. Where nationally, people are pressured to come together under a united stance on issues to sway political agendas, can a localized slate of differing, if only slightly, be included in these core beliefs of large political parties and national organizations. When organizations focus on the local to construct their core stances they risk alienating others on the national scale who have been forced to center their stances to appeal to voters across the country not just in a single voting district (e.g. the 51st district of West Virginia's state legislature). As national organizations attempt to appeal to a wide variety of voters, they risk turning away local organizations that do not agree with the 
more widely appealing view. What I am asking here is whether local and national political stances can coexist on a level that allows cooperation in the face of an extreme passion that risks dividing the political left? I argue that it is the national that needs to be flexible to the local. West Virginia is an example of this. The state is seen as more conservative but not extremely radical on many fronts with small pockets of progressivism in more populated areas. Progressivism in the state must negotiate with this conservatism to exist. MFP has taken its progressive views and intertwined them with local more conservative views to attract more politically centrist voters in the state. MFP as an organization agrees with many nationally held political views but works to frame them within a more accessible way that does not imminently push away more conservative voters. This is where the ambiguity of progressivism, the need to be adaptable to the local, becomes essential to the survival of progressivism.

MFP's ability to perform a balancing act between attracting local voters and being agreeable with nationally held progressive views stems from its West Virginia roots in a small college town alongside its membership ranging from extreme leftists to more moderate centrists (though most of its membership does lean politically to the left regardless of how they identify). A core goal, of MFP, is to promote progressive values in West Virginia, but in a state that voted overwhelmingly for Conservative Republican Donald Trump this requires more than toting progressive values and having people flock to the organization. Although this is what happens in the early days after the 2016 Presidential election as West Virginia progressives were searching for a place of safe harborage in a conservative state to be around like-minded people, it would not work as well when it came to further recruitment and future elections. Over the past 2 years of working with MFP, I have seen the unique ability of compromise come to life as the organization grows. Also, how a focus on local issues, as opposed to touting ideals can sway voters to cross party lines to support candidates and organizations that normally they would scoff at simply at from the safety of what is familiar. Progressivism does not simply have to a grouping of political ideals, instead, it should be a way of framing actions in a way that carries those actions into the political realm to speak for a movement. When others simply speak, progressivism should show and, in the end, hopefully, those actions with speak louder than words ever could in garnering peoples support and keeping it. 


\subsection{Summary of Findings}

Below are the eight principle findings of this research.

1. Emotional labor is present in every aspect of activism.

2. Emotions, in the form of moral shocks, serve to get people politically involved, but are not as effective in keeping them involved over the long term.

3. Creating space of belonging within socially negotiated spaces where activists feel they are welcomed is vital to their sustained involvement.

4. Facilitating the creation of social space and atmospheres is equally as important as public actions.

5. In the case of West Virginia Progressives, activists continue to be involved because they build community within the movement.

6. Extreme passion can lead to merciless infighting.

7. Infighting creates spaces of un-belonging were members do not feel welcome, even those who were not a part of the conflict.

8. Once infighting is settled, those who remain are more committed to the movement and organization.

\section{Conclusion}

I conducted this research originally to understand better what drives West Virginia progressive activists to sustain their activism over the long term, why they stayed involved even though they had very few victories. Using a longitudinal approach woven with semi-structured interviews, and participant kept diaries, I aimed to answer questions on what motivated them to stay involved. My findings show that it is the other people, the other activists, that keep them involved. By creating a space for community and belonging within the movement, activists can persevere through countless struggles and losses from inside and outside the movement by relying on each other. The experience of shared emotions is central to this creation of belonging, building on the need to feel as if they are a part of a community that shares in their struggles, both political and emotional. As geography's interest in belonging and the study of emotional geographies 
continues to grow, this research situates the importance of both kinds of literature within social movement research.

Building on Bosco's 'emotional labor' of political involvement concept, this research shows that progressive activism in West Virginia is permeated with emotion on all levels (2006). Starting in November of 2016, when the election results rang in with Trump's victory creating a 'moral shock' (Jasper and Poulsen, 1995; Cass and Walker, 2009) through the progressive community of the state, and the nation, that led to the creation or revitalization, as we see with MFP, of activist organizations. In MFP, I found that members work together, even without realizing it, to come together to create a space where they can express their shared emotions of sadness, frustration, and despair for the future of the state and nation. The potential of these created emotional spaces is exerted back onto those present (Massumi, 2002), facilitating a community that allows for those involved to express their own struggles which have shown to be a key factor in people's continued involvement in MFP.

This research shows that the creation of spaces of belonging (Antonsich, 2010) within an activist organization is a crucial component of its member's continued involvement in the organization. MFP has shown that creating a sense of community is equally as crucial as sponsoring public actions with political agendas. By shifting into this more social role, MFP has not only grown its numbers but fostered a more passionate and dedicated membership that is more likely to stay involved. These spaces of belonging and community show that a focus on the sustained involvement of members through ensuring that they feel as if they belong to this community of activist is a core strategy that can be adopted by other organizations to ensure continued involvement by activists. Through this belonging and community, burnout is prevented by a shared sense of responsibility for each other's well-being (Laughton, 2006).

The antithesis of the creation of this community and sense of belonging is the effects that infighting can have on an organization, as has been discussed within MFP. When a small number of people create a space where others are uncomfortable, it can cause the sense of community that the organization has strived to create to wither away as those who cause the infighting create space of exclusion. Infighting stresses the negative emotions that brought people together in the first place (Cass and Walker, 2009). However, once the infighting has been overcome, the dedication of those who remain in the organization appears stronger than before. The surviving community 
of activists recreates a stronger space of belonging (Antonsich, 2010) having worked through what would seem to have been inevitable inter-organizational struggles. This infighting is a core aspect of community building within such organizations as MFP and within broader social movements that encompass such organizations. Without these moments and spaces of tension to reaffirm, or even reignite, the passion of those involved movements can begin to subside through complacency. During this research, such complacency began to occur within MFP with created social space with such tensions to arise. Once these tensions subsided, those who remained seemed more committed to the movement and organization than before.

As a result of this research, I have a few recommendations for social movements leaders and others involved in the process of social change and coalition building. (1) While this may sound repetitious, I cannot stress enough the importance of ensuring that those who have dedicated their time and energy to any cause of social change feel as if they belong. The original goal of this research was to discover why those involved stay involved regardless of consistent losses and little victory. This research has shown that it is because of the other activists that they created a community with. This community of activists, made stronger through victory, loss, bonding, and strife has ensured that the progressive movement of West Virginia has continued for almost two years. (2) Activist organizations should prioritize facilitating social events for members to build community. These events that create social space for the activists to bond and recharge are equally as important as those public actions used for recruitment and to pressure elected officials. (3) MFP is a pledged movement that operates within the bubble of a university town on topics they feel are essential. While many members are affected by the policies they combat, they are not in immediate danger a majority of the time and can step back if needed to recharge. It is important to realize when movements and organizations operate with privilege and to use this privilege to help other organizations, members of the community, and movements to achieve their goals as well. (4) Finally, I come back to my original assumption when I began this research; it is vital to take time for yourself as an activist when you are beginning to feel burnt out. The organization is only as effective as everyone in it and if every member is burnout, so will the organization itself.

$-\mathrm{RJ}$ 


\section{$\underline{\text { References Cited: }}$}

Amin, A. (2005). Take the White out of the Union Jack. Paper delivered at the conference on Politics and Ethnicity, Merton College, Oxford: Oxford University.

Amir, M., and Kotef, H. (2015). Limits of dissent, perils of activism: Spaces of resistance and the new security logic. Antipode, 47(3), 671-688. http://doi.org/10.1111/anti.12130

Anderson, B. (2006). Becoming and being hopeful: Towards a theory of affect. Environment and Planning D: Society and Space, 24(5), 733-752. https://doi.org/10.1068/d393t

Ansell, N. (June 01, 2001). Producing Knowledge about 'Third World Women': the Politics of Fieldwork in a Zimbabwean Secondary School. Ethics, Place \& Environment, 4, 2, 101116

Antonsich, M. (2009). On territory, the nation-state and the crisis of the hyphen. Progress in Human Geography 33 (6) (forthcoming).

Antonsich, M. (2010). Searching for Belonging 2013; An Analytical Framework. Geography Compass, 4(6), 644-659. https://doi.org/0.1111/j.1749-8198.2009.00317.x

Askins, K. (2009). “That's just what I do': Placing emotion in academic activism. Emotion, Space and Society, 2(1), 4-13. http://doi.org/10.1016/j.emospa.2009.03.005

Askins, K. (2009b). “That's just what I do': Placing emotion in academic activism. Emotion, Space and Society, 2(1), 4-13. http://doi.org/10.1016/j.emospa.2009.03.005

Bauman, Z. (2006). Liquid Fear. Polity Press, London.

Berelowitz, J. (2005). The spaces of home in Chicano and Latino representations of the San Diego - Tijuana borderlands (1968-2002). Environment and Planning D: Society and Space 23, pp. 323-350.

Bethune, S., Lewan, E. (2017). Many Americans Stressed about Future of Our Nation, New APA Stress in America ${ }^{\mathrm{TM}}$ Survey Reveals. Retrieved September 28, 2017, from http://www.apa.org/news/press/releases/2017/02/stressed-nation.aspx

Brickell, K. (2012) Geopolitics of Home. Geography Compass, 6(10). 575-588.

Blunt, A. Dowling, R. M. (2006). Home. London, New York: Routledge.

Bohme, G. (2013). The art of the stage as a paradigm for an aesthetics of atmospheres. Ambiances. Retrieved from http://ambiances.revues.org/31 
Bolton, M., Froese, S., Jeffrey, A. (2016). "Go get a job right after you take a bath": Occupy Wall Street as Matter Out of Place. Antipode, 48(4), 857-876.

http://doi.org/10.1111/anti.12226

Bosco, F. J. (2006). The Madres de Plaza de Mayo and three decades of human rights' activism: Embeddedness, emotions, and social movements. Annals of the Association of American Geographers, 96(2), 342-365. https://doi.org/10.1111/j.14678306.2006.00481.x

Bosco, F. J. (2007). Emotions that build networks: Geographies of human rights movements in Argentina and beyond. Tijdschrift Voor Economische En Sociale Geografie, 98(5), 545563. http://doi.org/10.1111/j.1467-9663.2007.00425.x

Brown, G., Pickerill, J. (2009). Editorial: Activism and emotional sustainability. Emotion, Space and Society, 2(1), 1-3. http://doi.org/10.1016/j.emospa.2009.05.005

Botterill, K., Hopkins, P., Sanghera, G., Arshad, R. (2016). Securing disunion: Young people's nationalism, identities and (in)securities in the campaign for an independent Scotland. Political Geography, 55, 124-134. http://doi.org/10.1016/j.polgeo.2016.09.002

Burridge, A. (2010). Youth on the line and the No Borders movement. Children's Geographies, 8(4), 401-411. https://doi.org/10.1080/14733285.2010.511005

Cass, N., Walker, G. (2009). Emotion and rationality: The characterisation and evaluation of opposition to renewable energy projects. Emotion, Space and Society, 2(1), 62-69. http://doi.org/10.1016/j.emospa.2009.05.006

Chatterton, P., Pickerill, J. (2010). Everyday activism and transitions towards post-capitalist worlds. Transactions of the Institute of British Geographers, 35(4), 475-490. http://doi.org/10.1111/j.1475-5661.2010.00396.x

Chenoweth, E., and Pressman, J. (2017). Analysis | This is what we learned by counting the women's marches. From: https://www.washingtonpost.com/news/monkeycage/wp/2017/02/07/this-is-what-we-learned-by-counting-the-womensmarches/?utm_term=.f7211735903b

Cho, J., and Trent, A. (2006). Validity in qualitative research revisited. Qualitative Research, 6(3), 319-340. http://doi.org/10.1177/1468794106065006

Crang, M. (2005). Qualitative methods: there is nothing outside the text? Progress in Human Geography, 29(2), 225-233. http://doi.org/10.1191/0309132505ph541pr 
Creswell, J. (2003). Research Design: Qualitative, Quantitative, and Mixed Methods Approaches. Sage Publications.

DeLyser, D. (2001). “Do You Really Live Here?” Thoughts on Insider Research. Geographical Review, 91(1/2), 441-453. https://doi.org/10.2307/3250847

Dickinson, J., Andrucki, M. J., Rawlins, E., Hale, D., Cook, V. (2008). Introduction: Geographies of everyday citizenship. Acme, 7(2), 100-112.

Elliott, H. (1997) The use of diaries in sociological research on health experience Sociological Research Online

Ellis, C. and Bochner, A. (2000) 'Autoethnography, Personal Narrative, Reflexivity: Researcher as Subject', in N.K. Denzin and Y.S. Lincoln (eds) Handbook of Qualitative Research, 2nd Edition, pp. 733-68. Thousand Oaks, CA: Sage

Ellis, C., Adams, T. E., and Bochner, A. P. (2011). Autoethnography: An Overview Authors: Carolyn Ellis, Tony E. Adams and Arthur P. Bochner and Institutions from a Historical Perspective

Fenster, T. (2005). The right to the gendered city: Different formations of belonging in everyday life. Journal of Gender Studies, 14(3), 217-231. https://doi.org/10.1080/09589230500264109

Flesher, F., C. (2016). Cultural Barriers to Activist Networking: Habitus (In)action in Three European Transnational Encounters. Antipode, 48(1), 151-171. https://doi.org/10.1111/anti.12166

Fraser, N. (2017). The End of Progressive Neoliberalism. (n.d.). Retrieved from https://www.dissentmagazine.org/online_articles/progressive-neoliberalism-reactionarypopulism-nancy-fraser

Geertz, C. (1983). Local Knowledge: Further Essays in Interpretative Anthropology. New York: Basic Books

Geertz, C. (2000). Local knowledge: Further essays in interpretive anthropology. New York: Basic Books

Geoghegan, H. (2013). Emotional geographies of enthusiasm: Belonging to the Telecommunications Heritage Group. Area, 45(1), 40-46. http://doi.org/10.1111/j.14754762.2012.01128.x 
Gorski, P. C., and Chen, C. (2015). "Frayed All Over:" The Causes and Consequences of Activist Burnout Among Social Justice Education Activists. Educational Studies, 51(5), 385-405. http://doi.org/10.1080/00131946.2015.1075989

Halvorsen, S. (2015). Taking space: Moments of rupture and everyday life in occupy London. Antipode, 47(2), 401-417. http://doi.org/10.1111/anti.12116

Harper, D. (1998). On the authority of the image: visual methods at the crossroads. In Collecting and Interpreting Qualitative Materials. Eds Denzin N, Lincoln Y. Sage London. Pp 130-149.

Herbert, S. (2007). The "Battle of Seattle" revisited: Or, seven views of a protest-zoning state. Political Geography, 26(5), 601-619. http://doi.org/10.1016/j.polgeo.2007.04.004

Hopkins, P., Todd, L. (2015). Creating an intentionally dialogic space: Student activism and the Newcastle Occupation 2010. Political Geography, 46, 31-40. http://doi.org/10.1016/j.polgeo.2014.10.008

Ilcan, S. (2002). Longing in Belonging. The Cultural Politics of Settlement. Westport, Conn. Praeger.

Jasper J. M., Poulsen J. D. (1995) Recruiting strangers and friends: Moral shocks and social networks in animal rights and anti-nuclear protests. Social Problems 42(4):493-512

Juris, J. S. (2008). Networking Futures: the movements against corporate globalization. Durham, NC: Duke University Press.

Kannabiran, K., Vieten, U. M., et al. (2006). Boundaries, identities, and borders: exploring the cultural production of belonging - Introduction. Patterns of Prejudice 40 (3), pp. 189-195.

Kinney, C. (2018). A Culture of Resistance. Retrieved from https://www.laphamsquarterly.org/roundtable/culture-resistance

Latham, A. (2003). Research, performance, and doing human geography: Some reflections on the diary-photograph, diary-interview method. Environment and Planning A, 35(11), 1993-2017. http://doi.org/10.1068/a3587

Laughton, R., (2006). Walking your talk. Permaculture Magazine 47, 16-20

Leitner, H. (2012). Spaces of Encounters: Immigration, Race, Class, and the Politics of Belonging in Small-Town America. Annals of the Association of American Geographers, 102(4), 828-846. https://doi.org/10.1080/00045608.2011.601204 
Leland, J. (2016). Bernie Sanders and Donald Trump Voters Share Anger, but Direct It Differently. Retrieved from https://www.nytimes.com/2016/01/31/us/bernie-sanders-anddonald-trump-voters-share-anger-but-direct-it-differently.html

Lewis, R. L. (2010). Labor History. Retrieved from https://www.wvencyclopedia.org/articles/1271

Longhurst R (1996) Refocusing groups: pregnant women's geographical experiences of Hamilton, New Zealand/Aotearoa Area 28 143-9

Massey, D. (2005) For Space. Sage Publications

Meek, D. (2012). YouTube and Social Movements: A Phenomenological Analysis of Participation, Events and Cyberplace. Antipode, 44(4), 1429-1448. https://doi.org/10.1111/j.1467-8330.2011.00942.x

Massumi, B. (2002) Parables for the virtual: movement, affect, sensation Duke University Press, Durham NC

McCorkel, J. A., Myers, K. (2003). What difference does difference make? Position and privilege in the field. Qualitative Sociology, 26(2), 199-231. http://doi.org/10.1023/A:1022967012774

McDowell, L. (1992). Doing gender: feminism, feminists and research methods in human geography. Transactions, Institute of British Geographers, 17(4), 399-416. http://doi.org/10.2307/622707

Meth, P. (2003). Entries and omissions: Using solicited diaries in geographical research. Area, 35(2), 195-205. http://doi.org/10.1111/1475-4762.00263

Morris, B. (n.d.). History of Lesbian, Gay, Bisexual and Transgender Social Movement. http://www.apa.org/pi/lgbt/resources/history.aspx

Mountaineers for Progress. (n.d.). From https://www.mountaineersforprogress.com/strategicframework/

Mullis, D., Belina, B., Petzold, T., Pohl, L., Schipper, S. (2016). Social protest and its policing in the "heart of the European crisis regime": The case of Blockupy in Frankfurt, Germany. Political Geography, 55, 50-59. http://doi.org/10.1016/j.polgeo.2016.07.001

Nelson, J. (2016). Using conceptual depth criteria: addressing the challenge of reaching saturation in qualitative research. Http://Dx.Doi.Org/10.1177/1468794116679873, (2010), 69-71. http://doi.org/10.1177/1468794116679873 
Nicholls, W. (2009). Place, networks, space: theorizing the geographies of social movements. Transactions of the Institute of British Geographers, 34, 78-93.

New York Times. West Virginia Election Results 2016. (n.d.). From https://www.nytimes.com/elections/results/west-virginia

Ohio Valley Together. From https://www.facebook.com/pg/ovtogether/about/?ref=page_internal

Oppenheimer, A. (n.d.). Trump's win is a blow to globalization that may lead to an era of nationalist populism. Retrieved October 19, 2017, from http://www.miamiherald.com/news/local/news-columns-blogs/andresoppenheimer/article113974588.html

Oswin, N., Olund, E. (2010). “Governing Intimacy.” Environment and Planning D: Society and Space 28: 60-67

Pitts, M. J., Miller-Day, M. (2007). Upward turning points and positive rapport-development across time in researcher-participant relationships. Qualitative Research, 7(2), 177-201. http://doi.org/10.1177/1468794107071409

Pulido, L. (2003). The interior life of politics. Ethics. Place and Environment 6, 46-52.

Reissman, C. K. (2000). Stigma and everyday resistance practices. Gender \& Society, 14, 111-135.

Rose, G. (2001). Visual Methodologies. London: Sage Publications.

Sachs, J. D. (2011, November 12). The New Progressive Movement. Retrieved from https://www.nytimes.com/2011/11/13/opinion/sunday/the-new-progressivemovement.html

Smith, S. (2013). "In the past, we ate from one plate": Memory and the border in Leh, Ladakh. Political Geography, 35. 47-59.

Spiegel, J. B. (2015). Reve General Illimite: The role of creative protest in transforming the dynamics of space and time during the 2012 Quebec Student strike. Antipode, 47(3), 770-791. http://doi.org/10.1111/anti.12133

Sydell, L. (2017On Both the Left and Right, Trump Is Driving New Political Engagement. from http://www.npr.org/2017/03/03/518261347/on-both-left-and-right-trump-is-drivingnew-political-engagement

Thomas, F. (2007). HIV / AIDS and security. Area, 39(1), 74-82. 
Vikan, A. (2017). A fast road to the study of emotions: An introduction. Cham, Switzerland: Springer.

Watson, C. A., Till, K. E. (2015). The SAGE Handbook of Qualitative Geography Ethnography and Participant Observation, 121-137. http://doi.org/10.4135/9780857021090.n9

Wilkie A, Michael M and Plummer-Fernandez M (2015) Speculative method and Twitter: Bots, energy and three conceptual characters. The Sociological Review 63(1): 79-101.

Wilkinson, S. (2017). Drinking in the dark: shedding light on young people's alcohol consumption experiences, Social \& Cultural Geography, 18:6, 739-757, DOI:10.1080/14649365.2016.1227872

West Virginia Citizen Action Group. (n.d.). from http://wvcag.org/about/

Women's March: Our Mission. (n.d.). from https://www.womensmarch.com/mission

Zimmerman, D. H., Wieder, D. L. (1977). The Diary: Diary-Interview Method. Urban Life, 5(4), 479-498. http://doi.org/10.1177/089124167700500406 


\section{Appendix A: Interview Questions}

Questions were used during two different interviews throughout the study, during both the initial interview and the second (diary) interview halfway through the study period. The order that the questions are presented does not reflect the order in which they were discussed during the interviews. Instead, they were intended to act as a guide to ensure that at a minimum, certain topics are discussed with each participant.

Background Questions:

- Age?

- Work?

- Education?

- Identities?

- Where are you from?

- Where do you live now?

How did you get involved in politics/activism?

How long have you been involved in activism? When did you get involved?

What issues are you involved in/ passionate about? Why?

- Any specific organizations?

- What is your involvement in those organizations?

Can you describe any victories, large or small, that you have achieved in your activism?

- Any setbacks?

Looking back on your activism, do you have any reflections or major revelations?

- Anything you would do differently?

How would you describe/define activism?

How do you feel going forward?

How do you define yourself politically?

- Why?

- What do you define as progressive politics?

What motivates you to continue being involved in politics?

What excites you about being involved?

- Any specific instances or stories about when you were excited to be involved?

Does being politically involved affect your life outside of politics? How so?

- Work? 
- Personal Life?

- Family?

How has your life changed since becoming politically involved?

How has your political involvement changed since the 2016 Presidential race?

- Election Night?

- January 20th?

Have you ever felt drained or 'burnt out' from your political involvement?

Have you ever experienced any hostility due to your political involvement?

- Among allies or inside an organization?

- From opposition?

Do you feel marginalized due to your political beliefs?

- Your activism?

Do you feel like you belong in (Organization)?

How does being involved in (Organization) impact your activism/political involvement?

Is there anything else you would like to discuss or add? 


\section{Appendix B: Participant Reflection Diary Instructions included in each diary}

Help on writing your diary...

Dear diary-writer,

Thank you for agreeing to be a part of this study and to write in this diary. This is an unusual method to use in a study but interviews alone can only tell you about what a person is thinking on a single day, not many days.

I would like you to feel free about what you write in this diary. As such, I will keep your names anonymous. Nothing you write in this diary will be able to be traced back to you. As writing in a diary takes time and effort and I do not expect you to write in it every day. On some days, you may write a lot, while on other you may only write a few words or nothing at all, this is completely fine. You may write whatever you want in this diary. With that being said, I am specifically interested in your day to day experiences of being an activist in West Virginia, how your daily life affects your involvement in your activism, and how your activism affects your day to day life. Include anything at all, no matter how small or insignificant you may think it is. Please try and fill in the following details with each entry:

1. WHEN are you writing about? (date/time)

2. WHERE did this take place?

3. WHAT happened? (describe the event or specific instance you are writing about)

4. HOW did you feel about what you are writing about?

5. WHY did this event take place \& WHY were you there?

While not all entries will be able to include something about all five points, please try your best to touch on as many of them as you can, especially the When, Where, and How prompts. Please write in sentences if possible and if there is anything else you would like to add to or elaborate on, please feel free to do so.

Please keep the diaries for the entirety of the eight-week study period. For the interview at the end of the study period, I will ask you to bring your diary with you so that I can look over it and ask you questions on what you wrote. Afterward, I will keep the original diary following the final interview of the study period. However, if you would like to maintain a copy for yourself, I will gladly make a copy for you.

Remember, that everything you write in this diary will only be seen by yourself and the other researchers. Your name will not be attached to this diary in any way and all information inside will be kept completely confidential. If you have any questions, feel free to contact me anytime at the information provided below.

Thank you,

Roger Jennette

Email: (Omitted for Publishing)

Phone: (Omitted for Publishing) 


\section{Appendix C: Participant Photo Diary Instructions}

Dear participant,

Thank you for agreeing to be a part of this study and to submit your photos. You are being asked to use your own personal camera or device with a camera to capture these photos and are not being supplied with a camera for the purpose of this study. This is not a typical method used in a study, but combined with the reflection diary you agreed to complete, these photos will help to add depth and detail to what you write about.

I understand that taking photos and sorting through them to decide which ones to submit takes time and effect. As such I do not expect you to submit photos of everything you do or write about in your reflection diary. On some days, you may have many photos to submit, on others you may have one or two photos to submit or none at all, this is completely fine. I want you to submit as many, or as little photos as you feel comfortable with.

I want you to feel free to submit any pictures you feel are relevant or important to this study. With that being said, I am specifically interested in photographs that display you participating in an activist event or the planning of one, photos of how your activism has affected your everyday life and vice versa, how your activism has affected your everyday life, and of anything that your may have written in your diary.

Please continue to submit your photos for the entirety of the eight-week study period. For the interview that will occur after the study period, I will ask you to bring copies of your photos or email them to me so that I can look over them and ask you to elaborate on the photos.

Remember, that all the photos you submit to this study will only be seen by yourself and the other researchers. Your name will not be attached to the photos in any way and they are kept completely confidential. Unless express permission is given by all identifiable persons in the photo is given, only photos with no identifiable factors will be used in public reports. If you have any questions, feel free to contact me anytime at the information provided below.

Thank you,

Roger Jennette

Email: (Omitted for Publishing)

Phone: (Omitted for Publishing) 